\title{
Life cycle analysis of environmental impacts of earthen materials in the Portuguese context: Rammed earth and compressed earth blocks
}

\author{
Jorge Fernandes ${ }^{a,}{ }^{*}$, Marco Peixoto a , Ricardo Mateus a, Helena Gervásio ${ }^{b}$

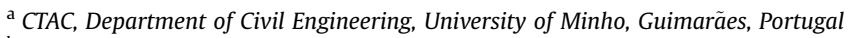 \\ ${ }^{\mathrm{b}}$ ISISE, Department of Civil Engineering, University of Coimbra, Coimbra, Portugal
}

\section{A R T I C L E I N F O}

\section{Article history:}

Received 13 May 2019

Received in revised form

21 August 2019

Accepted 3 September 2019

Available online 6 September 2019

Handling Editor. Baoshan Huang

\section{Keywords:}

Vernacular architecture

Life-cycle assessment

Environmental impacts

Rammed earth

Compressed earth block (CEB)

Earthen architecture

\begin{abstract}
A B S T R A C T
In the Portuguese context, the life cycle assessment of building materials is still in its infancy. So far, there is only a small number of Environmental Product Declarations (EPDs) available, all target for industriallybased materials. Although vernacular earthen materials are seen as ecological materials, with low potential environmental impacts, there are no studies that allow to quantitatively compare these materials with conventional ones, according to the applicable standards. In the case of Portugal, there are no EPDs or studies for these materials and the studies available worldwide are hard to compare, since they not follow the same life-cycle assessment methodology. This paper aims at contributing to a better understanding about the environmental performance of earthen materials by presenting results from the life cycle assessment of Compressed Earth Blocks (CEBs) and Rammed earth, based on specific life cycle inventory values obtained from a producer company, following the guidance provided by the standard EN15804. Among other conclusions, results show that CEB and Rammed earth have a total Embodied Energy of $3.94 \mathrm{MJ} / \mathrm{block}$ and $596 \mathrm{MJ} / 1 \mathrm{~m}^{3}$ and a Global Warming Potential of $0.39 \mathrm{~kg} \mathrm{CO}$ eq/block and $47.5 \mathrm{~kg} \mathrm{CO} 2$ eq. $/ 1 \mathrm{~m}^{3}$, respectively. In a cradle-to-gate analysis of different walls, the use of earthen building elements can result in reducing the potential environmental impacts in about $50 \%$, when compared to the use of conventional ones. Additionally, the advantages of using earthen materials are also discussed for the different building life-cycle stages, focusing on the possibility to recycle these materials in a closed-loop approach.
\end{abstract}

(c) 2019 Elsevier Ltd. All rights reserved.

\footnotetext{
Abbreviations: ADP_elements, depletion of abiotic resources - mineral elements; ADP_ff, depletion of abiotic resources - fossil fuels; AEC, architecture, engineering and construction; AP, acidification potential of soil and water; BSA, building sustainability assessment; CEB, compressed earth block; CED, method to calculate cumulative energy demand; CML-IA baseline, impact assessment method developed by the Center of Environmental Science of Leiden University; EE tot, total embodied energy; EP, eutrophication potential; EPD, environmental product declaration; GWP, global warming potential (climate change); LCIA, life cycle impact assessment; LCA, life cycle assessment; LCI, life cycle inventory; ODP, stratospheric ozone depletion potential; POCP, photochemical ozone creation; RE, rammed earth; U-Value, Heat transfer coefficient.

* Corresponding author.

E-mail addresses: jepfernandes@me.com (J. Fernandes), marco.amp@live.com.pt (M. Peixoto), ricardomateus@civil.uminho.pt (R. Mateus), hger@dec.uc.pt (H. Gervásio).
}

\section{Introduction}

\subsection{Framework}

The building industry is one of the largest sectors of worlds' economy, and one of the largest consumers of energy and raw materials/natural resources (Berge, 2009; Morel et al., 2001). Most of this problem is because the majority of the industrialised building materials that are used today have considerable environmental impacts in their production stage (Cabeza et al., 2013; J Fernandes et al., 2013; Wadel et al., 2010).

The global environmental awareness and the rising demand for environmentally friendly materials are pushing the sector to shift to the "sustainability" paradigm. Thus, the sector is slowly starting to adopt materials with lower embodied energy and other environmental impacts, and those that are more compatible, for instance, with the local climate context.

In order to promote the use of environmentally-friendly materials, there is a need to ensure an equative and quantitative 
comparison between building materials. Thus, the assessment of the environmental impacts of materials is essential to obtain comprehensive and more precise data, on all the stages of the life cycle of the building materials (extraction, processing, use, transportation and end-of-life scenarios). This assessment is complex, being difficult to describe all the impacts that result from all the life cycle stages (Cabeza et al., 2013; Sassi, 2006) and results cannot be directly extrapolated for specific local contexts (Wadel et al., 2010), mainly when products come from a remote source. Nevertheless, this information is essential to identify the materials that really have low embodied environmental impacts from those that only claim to be "green" and "eco" (Berge, 2009).

A way to communicate this information to the market is through the Environmental Product Declarations (EPDs). According to ISO 14025 (ISO, 2006a), EPDs are a type III environmental label that allow to communicate (business-to-business) quantified information on the environmental performance of products and services, based on the list of environmental life cycle assessment (LCA) parameters defined by the ISO 14040 group of standards (ISO, 2006b, 2006c). Since it allows to compare different products that meet the same functional requirement, it also fosters the competitiveness between manufacturers to improve the environmental performance of their products (Almeida et al., 2015; Ingwersen and Stevenson, 2012). According to Ibáñez-Forés et al. (2016), from the side of the companies the main factors for adopting EPDs, as an environmental communication tool, are the communication of objective information and the improvement of their corporate identity. Nevertheless, there is still a work to be done on the side of consumers regarding the interpretation of this information, since less than $40 \%$ consider that ecolabels provide clear and easy to understand information about the environmental impact of products (Ibáñez-Forés et al., 2016). Many companies consider this latter aspect as the main issue hampering the application of EPDs (Ibáñez-Forés et al., 2016).

Although the abovementioned advantages, it is difficult to compare products since the number of EPDs available is still scarce (Zackrisson et al., 2008). The fact that it is a voluntary declaration, involving a complex work and skilled professionals, is one of the barriers that explain the lack of EPDs, particularly for the products of small and medium-sized enterprises (Zackrisson et al., 2008). In the case of Portugal, the development of such information is still in its infancy - only ten EPDs are available (DAPHabitat, n.d.) covering only industrially-based building products.

Probably due to market communication strategies, the scale of production and the companies dimension, the EPDs available until now worldwide for construction products are only for industriallybased products (Eco Platform, n.d.; EPD International AB, n.d.).

In the case of vernacular materials (i.e. materials that are sourced, produced and applied locally, also known as traditional materials), these are frequently acknowledged as ecological due to the perceived lower embodied environmental impact, since most of these materials have low-tech processing and are low energy intensive. Although designers recognise this advantage in comparison with conventional materials, currently there is no quantitative data about the environmental performance of these materials, and no EPDs are available worldwide (Eco Platform, n.d.; EPD International AB, n.d.). The probable reasons to explain this are the local character of these materials, the heterogenic properties from site to site and consequently the difficulty to standardise, and the small production scale. This situation is hindering the use of these materials since LCA, or Building Sustainability Assessment (BSA) practitioners do not have the necessary quantitative data to show the environmental benefits of such materials to conventional practice.

In this context, this research work aims to provide a contribution to this field by assessing the life cycle performance of two earthen materials in compliance with standard EN15804, i.e., with Product Category Rules for Type III environmental product declaration of construction products (2012), based on data collected from a manufacturer of such materials, located in Portugal. Thus, the results of the assessment can be compared with other EPDs for construction materials or other materials assessed according to the same standard.

\subsection{Vernacular materials versus conventional materials}

The majority of conventional building systems rely on industrially-based materials with high embodied energy and other potential environmental impacts (e.g. concrete, aluminium, steel, glass, etc.) (Jorge Fernandes et al., 2013; Zabalza Bribián et al., 2011). There is the need to change the methods and production chains to follow a path towards environmental protection and sustainable management of resources, e.g., by closing the cycles of the products (Morel et al., 2001; Ramesh, 2012; Zabalza Bribián et al., 2011). To achieve this goal, it is necessary to move from a linear to a circular production model, which is characterised by a continuous cycle of recycling $>$ production $>$ use $>$ recycling, thus preventing the production of waste (Wadel et al., 2010). The actual linear production model dates back to the Industrial Revolution (about 250 years ago), and although all technological developments remain virtually unchanged (Wadel et al., 2010). Therefore, according to Wadel et al. (2010), the architecture, engineering and construction (AEC) industry should adopt a pre-industrial model in which the materials cycle was closed and the waste was reduced, i.e., a model of a society that was fundamentally organic, using biosphere resources according to the natural ability to produce them and assimilate the waste generated. Therefore, a possibility in the path to achieving a circular model is to revisit old habits and building techniques and to use the best current technical and scientific knowledge to improve them. Nevertheless, in the contemporary society and ways of living, this idea seems utopic.

To change this reality, several authors (Arrigoni et al., 2017; Cabeza et al., 2013; Chel and Tiwari, 2009; Morel et al., 2001; Ramesh, 2012; Shukla et al., 2009; Venkatarama Reddy and Jagadish, 2003) have focused their attention on researching alternatives to current building technologies. Some of these "alternatives" are, in fact, traditional or vernacular construction technologies used by communities for centuries.

The rising interest for vernacular materials and techniques on the scope of sustainable buildings comes from the following properties (i) close relation with local conditions, i.e., the materials are locally sourced; (ii) the techniques were developed in accordance to a specific climate; (iii) low requirements for transportation from the raw materials extraction to the manufacturing site; (iv) low embodied energy, due to the simpler manufacturing processes, and consequently reduced potential environmental impacts; (v) some materials are organic, biodegradable, renewable and can be framed into a "cradle-to-cradle" life-cycle approach (e.g. straw and reeds); and (vi) local manpower is used to produce them ( Fernandes et al., 2013). For example, the studies carried out by Fernandes et al. (2013), Zabalza Bribián et al. (2011) and Melià et al. (2014) have quantitatively compared several materials and concluded that vernacular and/or natural materials have considerable lower embodied energy and carbon dioxide emissions than conventional materials. These studies also highlighted the importance of promoting the use of low-processed and locally-sourced materials to reduce the embodied environmental impacts. The use of alternative building materials and techniques such as the vernacular ones (rammed earth, adobe, traditional vaults, etc.) can reduce environmental impacts, as shown by several studies 
(Praseeda et al., 2014)(Arrigoni et al., 2017; Christoforou et al., 2016; Melià et al., 2014; Sanz-Calcedo et al., 2012; Shukla et al., 2009; Venkatarama Reddy and Jagadish, 2003). Beyond the environmental advantages, Morel et al. (2001) and Ramesh (2012) also concluded that using local materials has socioeconomic benefits, such as to reduce the cost of construction and to foster local economies by paying the cost of the materials and labour locally.

For the reasons mentioned above, vernacular materials are relevant research subjects on the scope of the sustainability of the built environment and therefore it is necessary to develop detailed LCA studies in order to allow the comparison with conventional materials.

\subsection{Earth as an ecological building material}

Earth has been used as a building material for thousands of years, and a third of the world's population is still living in earthen buildings (Minke, 2006). Although these figures reveal the importance of earthen building techniques nowadays, these are being abandoned due to the connotation with poverty and to the dissemination of materials which allow a faster building process, such as the concrete (Leitão et al., 2017). Nevertheless, in the last decades, earthen techniques have re-gained an increasing interest due to the awareness around environmental issues (Arrigoni et al., 2017; Dabaieh, 2015; Jaquin et al., 2008; Leitão et al., 2017). Some studies have shown that the use of earthen materials can significantly reduce the potential environmental impacts of buildings $(J$ Fernandes et al., 2013; Hamard et al., 2016; Melià et al., 2014; Sanz-Calcedo et al., 2012; Shukla et al., 2009; Venkatarama Reddy and Jagadish, 2003; Venkatarama Reddy, 2009; Venkatarama Reddy and Prasanna Kumar, 2010). From the review paper by Cabeza et al. (2013), it can be highlighted that the materials with the best performance, at the level of embodied energy and $\mathrm{CO}_{2}$ emissions, are timber and earthen materials. Regarding the materials/building systems similar to the ones that are the research objects of this paper, rammed earth is one of the most common, and it is divided usually into two types: stabilised and nonstabilised rammed earth. The difference between the two is that stabilised rammed earth contains additives (cement or lime) to overcome some weaknesses of the soil used. For non-stabilised rammed earth walls, and depending on the production process, it can be stated that it is a more environmentally-friendly solution (Arrigoni et al., 2017; Cabeza et al., 2013).

Regarding cement stabilised rammed earth walls, Venkatarama Reddy \& Prasanna Kumar (2010) quantified the total embodied energy of this solution and concluded that it increased linearly with the increase in cement content $\left(400-500 \mathrm{MJ} / \mathrm{m}^{3}\right.$ for a cement content in the range of 6-8\%). Arrigoni et al. (2017) have also focused on analysing the environmental impacts of several stabilised rammed earth solutions and concluded that it is possible to have durable stabilised rammed earth mixes without using stabilisers with high potential environmental impact. Moreover, they stated that the environmental performance of the mixes was heavily influenced by cement manufacture and transportation (Arrigoni et al., 2017).

In what concerns to earthen blocks, Shukla et al. (2009) used the LCA method to analyse the embodied energy of an adobe house and concluded that it had a lower life cycle environmental impact than conventional buildings. By using low energy-intensive materials, the reduction of $\mathrm{CO}_{2}$ emissions was of about 101 tons/year. Chel and Tiwari (2009) have also studied the embodied energy of adobe buildings, but with vaulted roofs. According to this study, the embodied energy of a conventional housing with a reinforced concrete structure and about $95 \mathrm{~m}^{2}$ of floor area is of $3702.3 \mathrm{MJ} / \mathrm{m}^{2}$; while for the adobe building, the value is of $2298.8 \mathrm{MJ} / \mathrm{m}^{2}$. In the specific context of India, the authors concluded that adobe buildings are more eco-efficient than those built with conventional building materials.

Although these studies are relevant to understand the impact of choosing conventional or alternative building solutions, they are do not based on the standardised LCA method and/or they use generic life-cycle inventory data, i.e. data that do not consider the real manufacturing contexts of the materials used. The LCA studies carried out by Maza (2012), and Aillapán (2012) follow the methodology defined in standards ISO14040 and 14044 and are on CEBs manufactured in the specific context of two South American countries. The first study analysed five types of walls, in a cradle to gate perspective, to compare the environmental performance. The study considered the following materials for the walls: concrete hollow blocks; fired ceramic brick; and CEBs with different stabilisers (cement-lime, lime and gypsum). The author used the Ecoindicator 99 life cycle impact assessment method to quantify the potential environmental impacts and the results show that for $1 \mathrm{~m}^{2}$ of wall, the ceramic brick wall has four times more impact than concrete blocks, five times more than CEB (cement-lime) and eight and thirteen times more than CEB (lime) and CEB (gypsum), respectively (Maza, 2012). These results also showed that a reduction in the cement content results in a decrease in environmental impacts. Additionally, the study also showed that the industrialisation of the manufacturing and construction processes increased the embodied environmental impacts. However, this study has not considered the energy used by the equipment during the manufacturing of the product and the data sources for several processes are based on scenarios and literature.

The study conducted by Aillapán (2012) used the Cumulative Energy Demand and IPCC2007 methods. The results showed that the embodied energy of $1 \mathrm{~m}^{2}$ wall of CEB (including mortar) was of $104 \mathrm{MJ}$ and the GWP of $13.4 \mathrm{~kg} \mathrm{CO} 2$ eq. For 1 block, the total embodied energy was of $1.03 \mathrm{MJ}$ and the GWP of $0.0494 \mathrm{~kg} \mathrm{CO}_{2}$ eq. Although it follows the procedures of the standards, several processes were not considered (e.g. transportation of ancillary materials, soil preparation and mixing equipment) and some processes are based on the use of generic data. These two studies showed the potential of these materials for sustainable building. Nevertheless, the fact that these two studies used different methods to assess the environmental impacts and embodied energy, which makes difficult to compare the results.

In the Portuguese context, Pereira (2017) assessed the life cycle environmental impacts for a specific Compressed Earth Block (CEB) developed in the scope of a research project. The author concluded that the CEB Wall had lower environmental impacts and embodied energy than a conventional hollow brick wall. Analysing the Global Warming Potential category, the CEB had 27\% less impact than the conventional wall, $19.8 \mathrm{~kg} \mathrm{CO} 2$ eq. and $25.2 \mathrm{~kg} \mathrm{CO} 2$ eq., respectively. It has to be highlighted that although the CEB wall was three times heavier than the conventional wall, it stills had almost 30\% less impact. Although this kind of study is useful to understand and compare the environmental impacts of materials, it uses generic data from databases. The fact that the study does not use real data from a producer in a specific context may reduce the accuracy of the results and the analysis. This type of issue was also mentioned by Arrigoni et al. (2017) in their study. The use of different type of data is relevant because it is frequently difficult to compare the results of various studies for the same kind of material - because they have different sources of data, assessment methods, system boundaries, cut-off criteria, etc. - as stated by Almeida et al. (2015), particularly for non-conventional materials as the earthen ones. For the specific case of rammed earth, there was not found any study that follows the steps to develop an EPD.

In this context, environmental issues can be the turning point in 
favour of earthen materials. However, studies for specific regional contexts are needed so that the accuracy of the results allows a transparent comparison between materials within that context. Moreover, beyond these advantages there are also health and socioeconomic benefits (Berge, 2009; Chandel et al., 2016; Fernandes et al., 2015; J Fernandes et al., 2013; Minke, 2006), since, among others, these materials have low toxicity and the capacity to regulate indoor relative humidity; the valorisation and use of vernacular earthen techniques leads to the need to educate and train skilled construction workers, contributing to preserve local heritage and maintain a cultural legacy; and the local production of materials is economically cheaper, creates jobs and fosters local economies.

In Portugal, the development of Environmental Product Declarations (EPDs) for building materials and products is still in an early stage of implementation and is only oriented to industrially-based products. Therefore, although vernacular construction materials are perceived to be more environmentally friendly, there are no scientific-based studies that prove this better environmental performance. This situation is hindering the use of these materials in new constructions or refurbishing operations since LCA, or Building Sustainability Assessment (BSA) practitioners do not have the quantitative data to perform environmental life cycle assessments at the scale of buildings. There are many different vernacular building materials in Portugal, but in this study, the focus is in the development of the LCA of two of the most used materials, which have still potential to grow in the future, namely rammed earth and compressed earth blocks. Therefore, this paper aims to contribute to this field by presenting the results on the life cycle assessment of two earthen building materials produced in the Portuguese context. The results of the study can be useful to promote the environmental advantages of this type of vernacular materials and to support designers' decision-making on choosing low environmental impact materials.

\section{Materials and methods}

The LCA of Compressed Earth Blocks (CEB) and Rammed Earth (RE), produced by a Portuguese company located in the south of the country, municipality of Serpa, was done according to standard EN 15804 (CEN, 2012).

\subsection{Goal and scope definition}

The LCA of materials based on specific life cycle inventory data is essential for an accurate comparison. The goal of the study is to assess the potential environmental impacts and the total embodied energy in the production of CEBs and Rammed Earth. The research is focused on the "cradle-to-gate" stage, but also presents some scenarios for the remaining life-cycle stages. In addition, the study aims to identify the processes that most contribute to the life cycle potential environmental impacts.

In the end of this paper, a comparison between the two earthen products and conventional buildings materials is performed, based on a functional unit defined by $1 \mathrm{~m}^{2}$ of a wall.

\subsection{Life cycle impact assessment}

The life cycle inventory data was converted into environmental impacts using two life cycle impact assessment (LCIA) methods. The CML-IA baseline method (version 3.04) was used to assess the environmental indicators expressed in impact categories and the Cumulative Energy Demand (CED) method (version 1.09) was used to assess the life cycle energy inputs. The improvement of energy efficiency and the reduction of operating energy in buildings has emphasised the importance of the embodied energy in building materials. Therefore, to complement this study, the total embodied energy of the products was also assessed, considering the energy inputs of the processes within the considered system's boundaries.

SimaPro v8.4 software was used to model the life cycle of two construction products.

Table 1 lists the environmental indicators considered in this study and the respective LCIA method.

\subsection{Compressed earth blocks}

\subsubsection{Declared unit}

According to EN 15804 (CEN, 2012), in a "cradle to gate" analysis, a declared unit should be used instead of a functional unit. For the production of CEBs, the declared unit considered is 1 block, with dimensions 300x150x70 mm.

\subsubsection{System boundaries and description of the production system}

In the analysis of the Compressed Earth Blocks, the study covers the life cycle of the material, in a cradle to gate approach with options. Although the company has planned to implement processes to close the loop of the used materials (e.g. waste processing to recover/recycle the product), these have not been implemented yet. Therefore, since the company has no data to quantify the environmental impacts beyond de Product Stage, for the life cycle impact analysis of the CEBs production, only the mandatory stages of the production system were considered (Modules A1-A3) (Fig. 1). The information is presented according to the following information modules: A1 - Raw material supply, A2 - Transport and A3 Manufacturing. In addition to these information modules, technical information was declared for modules B, C and D, according to the scenarios defined by the company (Fig. 1), but the respective environmental impacts were not calculated. This method is preconized in standard EN15804 to ensure a proper understanding of the function of a product. Fig. 1 shows the diagram of processes of the CEBs, presenting all the inputs and outputs in each process, for all life cycle stages. This research is focused on presenting and analysing the impacts resulting from the production of the Compressed Earth Blocks (product stage, modules A1 to A3).

\subsubsection{Product stage}

2.3.2.1.1. Module A1 - Raw material supply. The compressed earth block under analysis is made mostly of soil (more than $80 \%$ ) with the addition of hydraulic lime and water. The raw material supply process considers the extraction of soil and the supply of ancillary materials. The main raw material is soil and is extracted in sites within a radius of $30 \mathrm{~km}$ from the CEB production plant. The soil extraction and loading of the lorry are carried out by a dieselpowered backhoe loader, with an average consumption of 14.55 1/ $\mathrm{h}$ at medium-load operation service. During the extraction process there is a first selection of the raw material - since the layer of soil that is suitable for construction (gravel, sand, silt, clay) is beneath the organic topsoil (agronomic soil). Additionally, before loading it into the lorry, the soil is roughly sieved to remove stones. The "waste" from the selection is returned to the extraction site. For secondary materials, i.e. materials used in the manufacturing process that are produced in other companies, e.g. hydraulic lime, or for which the company does not have direct influence or specific data, e.g. electricity mix, generic data from the Ecoinvent v3.3 life cycle inventory database was used.

2.3.2.1.2. Module A2 - Transport. In the process of transportation of raw materials/products to the production site, it was considered the travelling distance from the suppliers to the production unit of CEBs. The suppliers were the ones indicated by the manufacturer, i.e. where the manufacturer usually buys the needed raw materials/ 
Table 1

Environmental indicators and quantification methods.

\begin{tabular}{|c|c|c|}
\hline Environmental indicators & Unit & LCIA method \\
\hline Depletion of abiotic resources - mineral elements (ADP_elements) & $\mathrm{kg} \mathrm{Sb} \mathrm{eq}$ & CML-IA baseline v3.04 \\
\hline Depletion of abiotic resources - fossil fuels (ADP_ff) & MJ & CML-IA baseline v3.04 \\
\hline Global warming potential (GWP) & $\mathrm{kg} \mathrm{CO} 2$ eq & CML-IA baseline v3.04 \\
\hline Ozone depletion (ODP) & kg CFC-11 eq & CML-IA baseline v3.04 \\
\hline Photochemical ozone creation (POPC) & $\mathrm{kg} \mathrm{C}_{2} \mathrm{H}_{4}$ eq & CML-IA baseline v3.04 \\
\hline Acidification (AP) & $\mathrm{kg} \mathrm{SO}_{2}$ eq & CML-IA baseline v3.04 \\
\hline Eutrophication (EP) & $\mathrm{kg}\left(\mathrm{PO}_{4}\right)^{3-} \mathrm{eq}$ & CML-IA baseline v3.04 \\
\hline Embodied Energy (EE) & MJ & Cumulative energy demand v1.09 \\
\hline
\end{tabular}

products. A map application (e.g. Google Maps) was used to calculate the transportation. In the case of the soil, according to the data presented by the company, the extraction sites are located at an average distance of $30 \mathrm{~km}$. A diesel powered 7-ton lorry is used in the transportation of soil, and this vehicle is usually rented to a company that provides this kind of service. For the transportation of the other ancillary materials and products, namely the wrapping plastic film, hydraulic lime and wooden pallets, 7 to 32-ton diesel powered lorries, are used (Fig. 2). Fig. 2 presents the load capacity of the lorries used in the transportation processes and the transportation distance of each material/product used in the manufacturing process.

2.3.2.1.3. Module A3 - Manufacturing. The manufacturing process of the CEB comprehends the following unitary processes:

a) Administrative services - This process includes the office activity necessary for the company operation. In this process are included the water consumption and the energy used in the office. The public grid supplies both resources.

b) Raw materials reception and drying - the ancillary materials as lime, pallets and plastic film are received and stored. The soil is unloaded and stored in a protected place to dry.

c) Soil crushing and sieving - to obtain an adequate granulometry, the soil is crushed and afterwards sieved. The soil crusher (power $3.21 \mathrm{kWh}$; productivity $9 \mathrm{~m}^{3} / \mathrm{h}$ ) and the sieve (power $0.85 \mathrm{kWh}$; productivity $3 \mathrm{~m}^{3} / \mathrm{h}$ ) equipment are both electric and connected to the public grid. The soil that is "wasted" in the sieving process is recycled and used in other construction works of the company.

d) Mixing - In this process, all materials are mixed (soil $83.5 \%$, $6.5 \%$ hydraulic lime and $10 \%$ of water). A diesel-powered tracked dumper does the mixture with a concrete mixer and max payload of $1500 \mathrm{~kg}$ (fuel consumption of $3.2 \mathrm{l} / \mathrm{h}$ ). The mixing time for $1200 \mathrm{~kg}$ is of $15 \mathrm{~min}$. The mixture is unloaded next to the pressing machine.

e) Pressing - An automatic electric hydraulic press (power $9.54 \mathrm{kWh}$, productivity of 375 blocks/hour) is used in the process of casting and pressing the blocks. Although the equipment is automatic, two procedures are made manually, namely loading the hopper tank and removing the fresh blocks. The defective blocks return to the production cycle.

f) Drying - The fresh blocks are wet cured and dry out under ambient conditions for at least 28 days. In the wet cure, are consumed $10 \mathrm{l} / \mathrm{m}^{3}$ of water. No energy input is required in this process.

g) Handling and packaging - After the blocks are dried, they are stacked on a wooden pallet and wrapped in a plastic film. All the process is manual.

h) Storage - The pallets are properly stored for later shipment.

\subsubsection{Construction Stage scenario}

2.3.2.2.1. Module A4 - Transport. This module includes the transportation of the product, ancillary materials and equipment from the company's headquarters to the construction site. The travelling distance is variable, depending on the location of the construction site. Within the equipment frequently transported is included a skid-steer loader, a telescopic handler and a mixer. Since the equipment returns to the headquarters, the travelling distance has to be doubled. For this transportation, the company usually rents a diesel powered 32-ton lorry.

2.3.2.2.2. Module A5 - Construction. The construction process of a CEBs wall consists of laying the blocks with mortar. The mortar used is a mix of lime (usually $30 \%$ but the percentage may vary according to the type of soil) with soil and water. Regarding the finishing coating, there are several options since due to aesthetic properties of the product, the wall can be plastered, lime washed or just left in sight with no finishing. Thus, the type of chosen finishing can vary the environmental impact of a CEB wall.

\subsubsection{Use stage scenario}

2.3.2.3.1. Module B2 - Maintenance. In the use stage, was considered only the information module regarding the maintenance of the product (module B2). The other modules of the 'Use Stage' were not considered since they do not apply to this case or are less frequent and difficult to estimate during the service life (e.g. the repair or refurbishment actions depend on the degree of severity of the damage or the type of intervention). Thus, maintenance is the only relevant periodical operation to take into account. This module includes the following processes:

a) Transport - it includes the transportation of building products and equipment from the company headquarters to the building, namely lime and some small equipment and objects. The transport usually used is a diesel-powered van.

b) Whitewashing - The whitewash is the most common maintenance procedure, but the type of maintenance could vary depending on the type of finishing. The whitewash is a mix of lime and water. Traditionally, the quantity of quicklime is of $1 \mathrm{~kg}$ for 5 litters of water and allows to whitewash around $10 \mathrm{~m}^{2}$ of a wall with two coats. The wall must be wet in advance to the washing, but the quantity of water necessary may vary depending on air temperature and sun exposure. The period between whitewash is on average of $4-5$ years but can be longer. The whitewash is applied manually, and it is not required energy input in this process.

\subsubsection{End-of-life stage scenario}

2.3.2.4.1. Module C1 - Demolition. In the case of a CEB wall, the demolition process is no different from a conventional brick wall. In the process, it is normally used a diesel-powered backhoe digger or a mini-excavator with a hydraulic hammer, and occasionally it may be necessary to use manual demolition equipment such as jackhammers. The time required for the demolition process depends upon the type and size of the structure to be demolished. In this 
COMPRESSED EARTH BLOCKS

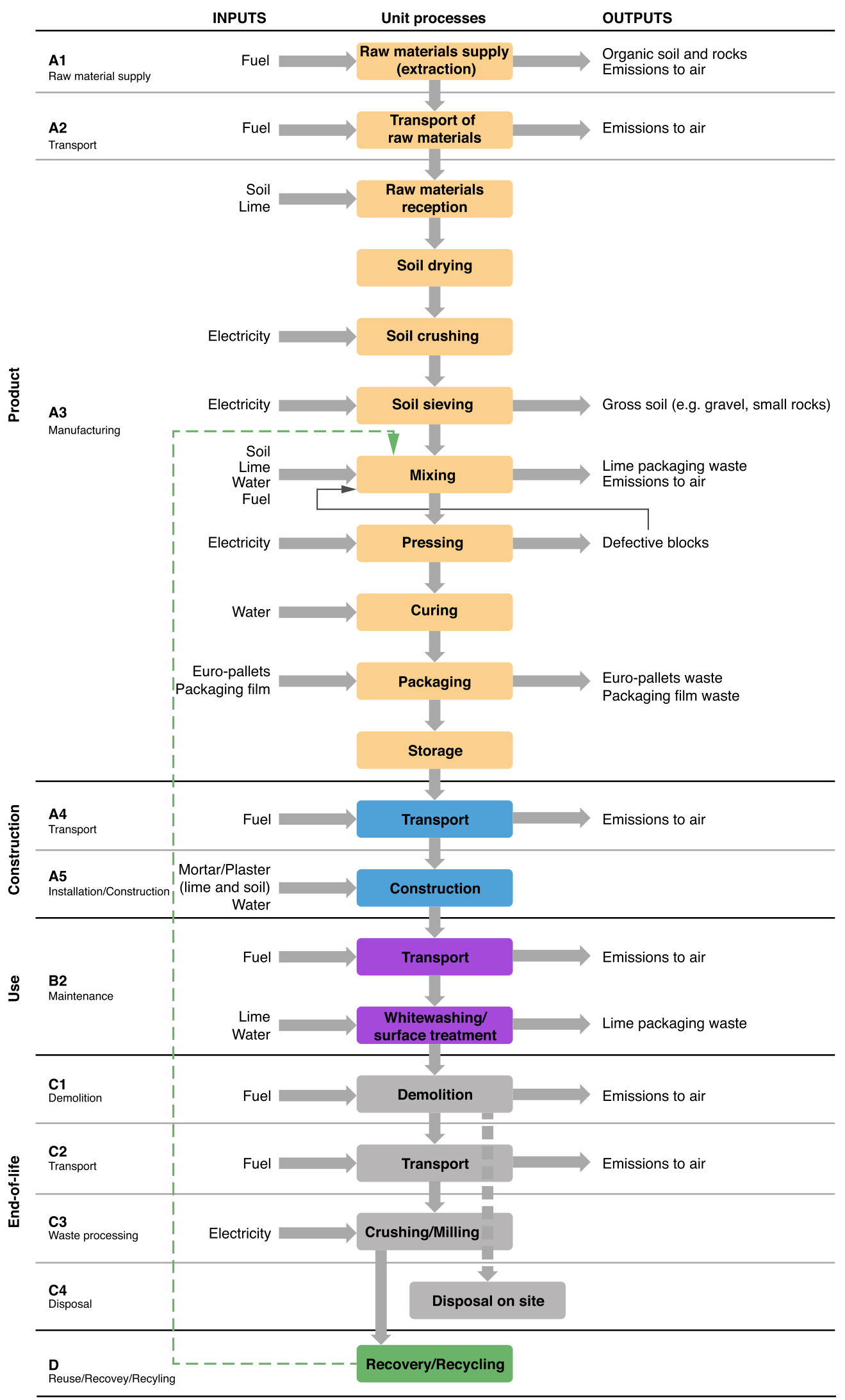

Fig. 1. Diagram of inputs and outputs of processes in the production of CEBs. 


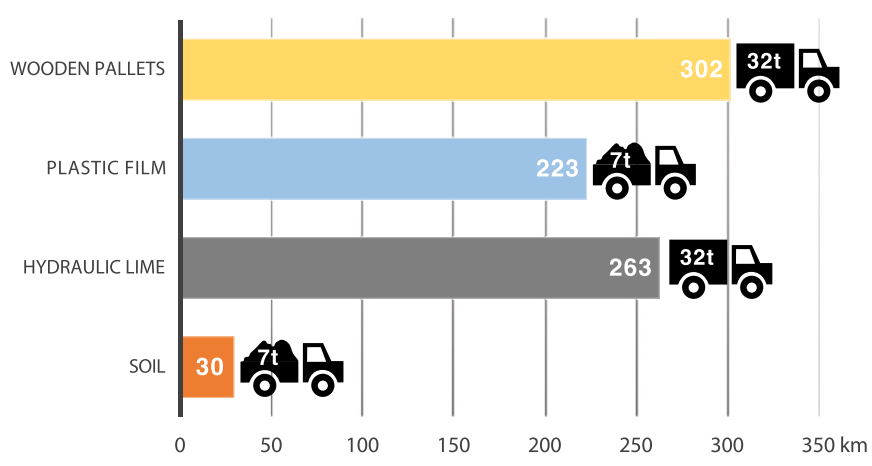

Fig. 2. Travelling distances and type of transportation for each material/product of the CEB production process.

process is included an on-site sorting of the demolition waste.

2.3.2.4.2. Module C2 - Transport. This module includes the transportation of the demolition waste to the company headquarters to be processed. The most suitable vehicle for this transportation is a diesel powered 32-ton lorry. The travelling distance is variable.

2.3.2.4.3. Module C3 - Waste processing. The waste processing is simple and has the purpose of recovering the material for a new product life cycle. It includes a process of crushing/milling the waste of the CEB wall (blocks and mortar). In this process is used an electrical jaw crusher. The resulting material is forwarded to the process of recovery/recycling (module D).

2.3.2.4.4. Module C4 - Disposal. In the demolition process, the company claims that it is possible to recover near $90 \%$ of the waste material. Therefore, the other $10 \%$ are lost waste (e.g. small broken parts, dust from demolition, etc.) that it is left in the building site. Since the product is mainly made from soil, there is no significant impact in returning it to the natural environment.

\subsubsection{Benefits and loads beyond the system boundary}

2.3.2.5.1. Module D - Recovery/Recycling. The process of recovery/recycling recovers the resulting material from waste processing (module C3) for a new cycle. The material is forwarded to the mixing process (Module A3) to be recycled into new CEBs. To be recycled, it is necessary to add $1 \%$, in volume, of hydraulic lime to increase the amount of binder of the mixture and to guarantee quality properties. The value of $1 \%$ of lime was provided by the manufacturer, according to their current experience on recycling defective dried blocks or dismantled walls. The use of the recovered material has economic and environmental benefits and does not changes the quality of the final product.

\subsubsection{Cut-off criteria}

According to EN 15804, the cut-off criteria for unitary processes is $1 \%$ of the total energy inputs and $1 \%$ of the total mass but should not exceed a total of $5 \%$ of energy and mass flows excluded from the product stage. The following processes from the CEBs production stage were excluded:

a) Internal transport - since the manufacturing equipment is in a production chain, i.e., very close to each other, the contribution of internal transport to potential environmental impacts is considered negligible;

b) Manual work, as it does not cause impacts;

c) Environmental loads related to the construction of the industrial facilities and production of equipment;

d) Maintenance of building facilities and equipment - the impacts attributed to the maintenance of facilities and equipment were not considered since they are difficult to quantify and have a low contribution in life cycle inventory (LCI) (Frischknecht et al., 2007);

e) In the administrative services the office consumables (e.g. office paper and tonners) were excluded since there was no purchase record history.

\subsubsection{Life cycle inventory}

In the CEBs product stage processes, specific data such as physical characteristics (dimensions and weight of the blocks), materials and quantities, type of equipment used, extraction capacity, time required for mixing, production capacity of the press, quantity of packaging products (European pallets and packaging plastic film), amount of waste and billing values (used for economic allocation) were provided by the company.

The fuel and electricity used by the equipment in processes like extraction, crushing, sieving and pressing take into consideration manufacturers technical sheets or data provided by them. The number of uses of a wooden pooled pallet took as reference the work of Bengtsson and Logie (2015) and considered 87 trips/uses during its life span.

The inventory data regarding transportation, consumed fuel and electricity, and production of hydraulic lime and packaging products, are based on the generic life cycle inventory Ecoinvent v3.3 database.

Table 2 presents the inputs and outputs to produce 1 CEB. Fig. 3 shows the raw materials flow to produce a CEB with $6,1 \mathrm{~kg}$ (Product Stage). Regarding the percentage of lime used, it should be noted that CEBs use more lime than rammed earth because the blocks need higher mechanical resistance to support handling and transportation after the curing process.

\subsubsection{Allocation procedures}

The business activity of the company is not only related to the production of compressed earth blocks but also includes rammed earth, and conventional construction works. Thus, to take into account the impacts of the unitary processes that are common to the various business activities, the financial allocation was used. In this case, a percentage of the revenue generated by each activity was applied.

A common process to all business activities are the administrative services, and in this case, it was considered the electricity and water use in the office. The considered information reports to the year 2016.

\subsection{Rammed earth}

\subsubsection{Declared unit}

In this case, the declared unit is $1 \mathrm{~m}^{3}$ of a rammed earth wall.

Table 2

Life cycle inventory per declared unit (1 CEB).

\begin{tabular}{lll}
\hline Inputs & Units & 1 CEB \\
\hline Soil & $\mathrm{kg}$ & $7.05 \mathrm{E}+00$ \\
Lime & $\mathrm{kg}$ & $2.51 \mathrm{E}-01$ \\
Water & $\mathrm{L}$ & $5.81 \mathrm{E}-01$ \\
Electricity & $\mathrm{kWh}$ & $3.26 \mathrm{E}-02$ \\
Fuel & $\mathrm{MJ}$ & $3.27 \mathrm{E}-01$ \\
European pallets & $\mathrm{un}$ & $1.15 \mathrm{E}-04$ \\
Packaging film & $\mathrm{kg}$ & $7.50 \mathrm{E}-04$ \\
Transport & ton.km & $2.57 \mathrm{E}-01$ \\
\hline Outputs & & \\
\hline Waste soil (gravel, etc.) & $\mathrm{kg}$ & $1.34 \mathrm{E}+00$ \\
Water (drying process) & $\mathrm{L}$ & $4.32 \mathrm{E}-01$ \\
\hline
\end{tabular}




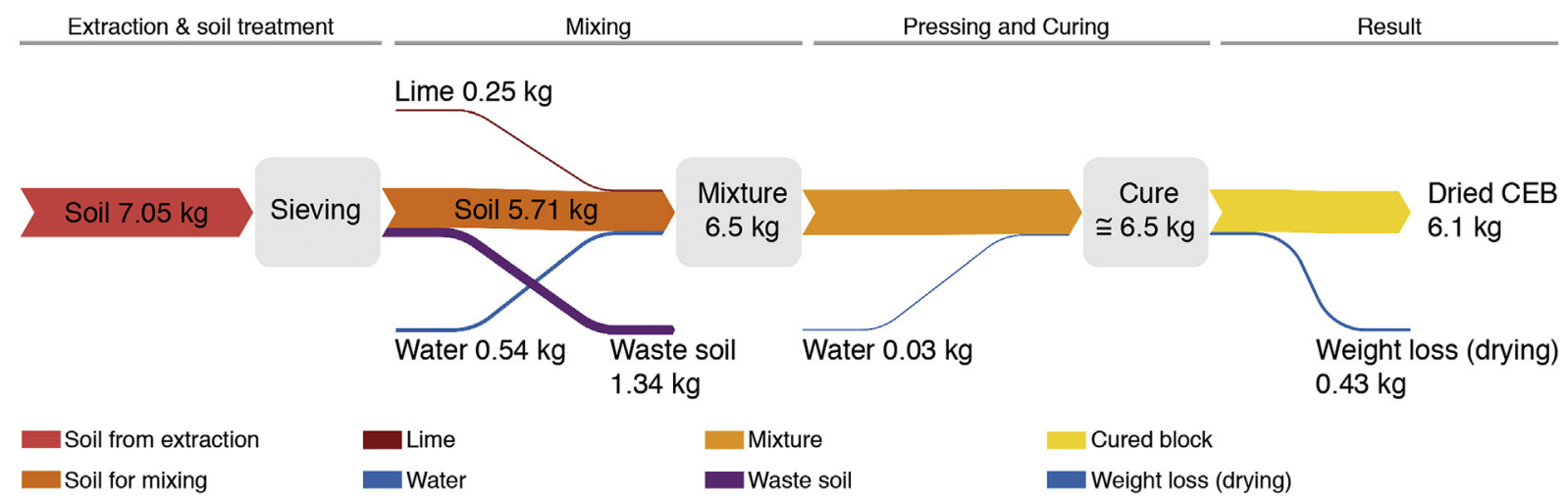

Fig. 3. Diagram of raw materials flows per declared unit (1 CEB).

\subsubsection{System boundaries and description of the production system}

In the case of Rammed Earth case, the study covers the stages from cradle to gate with options. As in the case of the CEBs, the company intends to close the loop of the product, but the necessary processes have not been implemented yet. Therefore, the company has no quantitative data for these processes, and it is difficult to predict the required time and resources. Moreover, even though it is possible to pre-cast rammed earth panels, the majority of this type of construction relies on the traditional way of on-site construction. Thus, in this study, some information modules in cradle to gate analysis are not applicable, and the modules of Construction Stage (A4-A5) had to be considered (Fig. 4). The environmental impacts were not quantified beyond the Construction Stage, and the modules were organised as follows: A1 - Raw materials extraction and supply; A4 - Transport of equipment and materials to the building site; and A5 - Installation/Construction. From information modules B - Maintenance to D - Recovery/recycling, the processes were described according to the scenarios provided by the company (Fig. 4), but the environmental impacts were not quantified. As already mentioned, this method is recommended by standard EN15804 to ensure a proper understanding of the function of a product. Fig. 4 shows the diagram of processes and presents all the inputs and outputs for each process of the life cycle stages.

The composition of the rammed earth walls varies from site to site according to the type of soil and its properties. Even in a region with adequate soils for rammed earth, sometimes there is the need to adjust de particle size distribution. If the soils to make this adjustment are sourced far from the building site, the overall environmental impacts will increase due to the impacts of the transportation processes. The company reported that when this adjustment is needed, the soils to do so are extracted as close as possible to the building site to minimise the transportation needs. Nonetheless, to consider these variables in this study would be complex since the adjustments may vary from site to site. Thus, in this study is considered the common scenario of adequate soils available in the building site or nearby, as reported by the company. Although it is possible to build a rammed earth wall without adding stabilisers, if the soil has a good quality, in this study it is considered the most common scenario, i.e. the addition of hydraulic lime. The conventional mixture used has the following percentages: $87 \%$ soil, $3 \%$ hydraulic lime and $10 \%$ of water.

\subsubsection{Product and Construction Stages}

2.4.2.1.1. Module A1 - Raw materials extraction and supply. The main raw material is soil and is extracted on-site by a dieselpowered backhoe loader, with an average consumption of $14.55 \mathrm{l} /$ $\mathrm{h}$ at an average-load operation service. During the extraction process, the soil is sieved to reject rough materials like rocks. The "waste" from the sieving process is returned to the extraction site.

The hydraulic lime necessary in the construction process has its origin in production units as closest as possible of the company's facilities.

2.4.2.1.2. Modules A4 - Transport. In the process of transportation of materials and equipment to the construction site, and since it is variable, based on the data provided by the company, it was considered that the average travelling distance from the company headquarters is of $30 \mathrm{~km}$.

In the equipment transported from the headquarters is included a skid-steer loader, a telescopic handler, a portable air compressor, pneumatic rammers, the formwork panels and the rented backhoe digger. Since the equipment returns to the headquarters, the average travelling distance considered was of $60 \mathrm{~km}$. The backhoe digger used in the extraction process is rented at an average distance of $5 \mathrm{~km}$ from the headquarters. This transportation is done by road using a diesel powered 32-ton lorry that is rented to a company that provides this kind of service.

For the transportation of the hydraulic lime, it was considered the distance from the supplier to the company's headquarters and from there to the construction site (both are in a 32-ton lorry) (Fig. 5). The environmental loads from the transportation processes are based on the generic inventory values from the Ecoinvent v3.3 database.

The travelling distances and the type of transport considered for the equipment and materials are presented in Fig. 5.

2.4.2.1.3. Modules A5 - Construction. In this module the following unitary processes are considered:

c) Administrative services - This process includes the office activity necessary for the company's operation, i.e., water and electricity use in the office.

d) Formwork assembly - This process consists in assembling the formwork elements to cast the rammed earth. Although this process is mostly manual, in some conditions the telescopic handler to lift the formwork panels can be used

e) Mixing - In this process, all raw materials are mixed $(87 \%$ soil, $3 \%$ hydraulic lime and $10 \%$ of water). In the mixture, it is used a diesel-powered skid-steer loader (fuel consumption of $6.8 \mathrm{l} / \mathrm{h}$ ). The mixing time for $2080 \mathrm{~kg}$ (approximately $1.66 \mathrm{~m}^{3}$ of the mixture used to build $1 \mathrm{~m}^{3}$ of rammed earth) is of about $15 \mathrm{~min}$.

f) Formwork loading - The mixture is poured into the formwork with a diesel-powered telescopic handler (fuel consumption of $9.12 \mathrm{l} / \mathrm{h}$, considering a mixed-use of cargo, handling, etc.). 


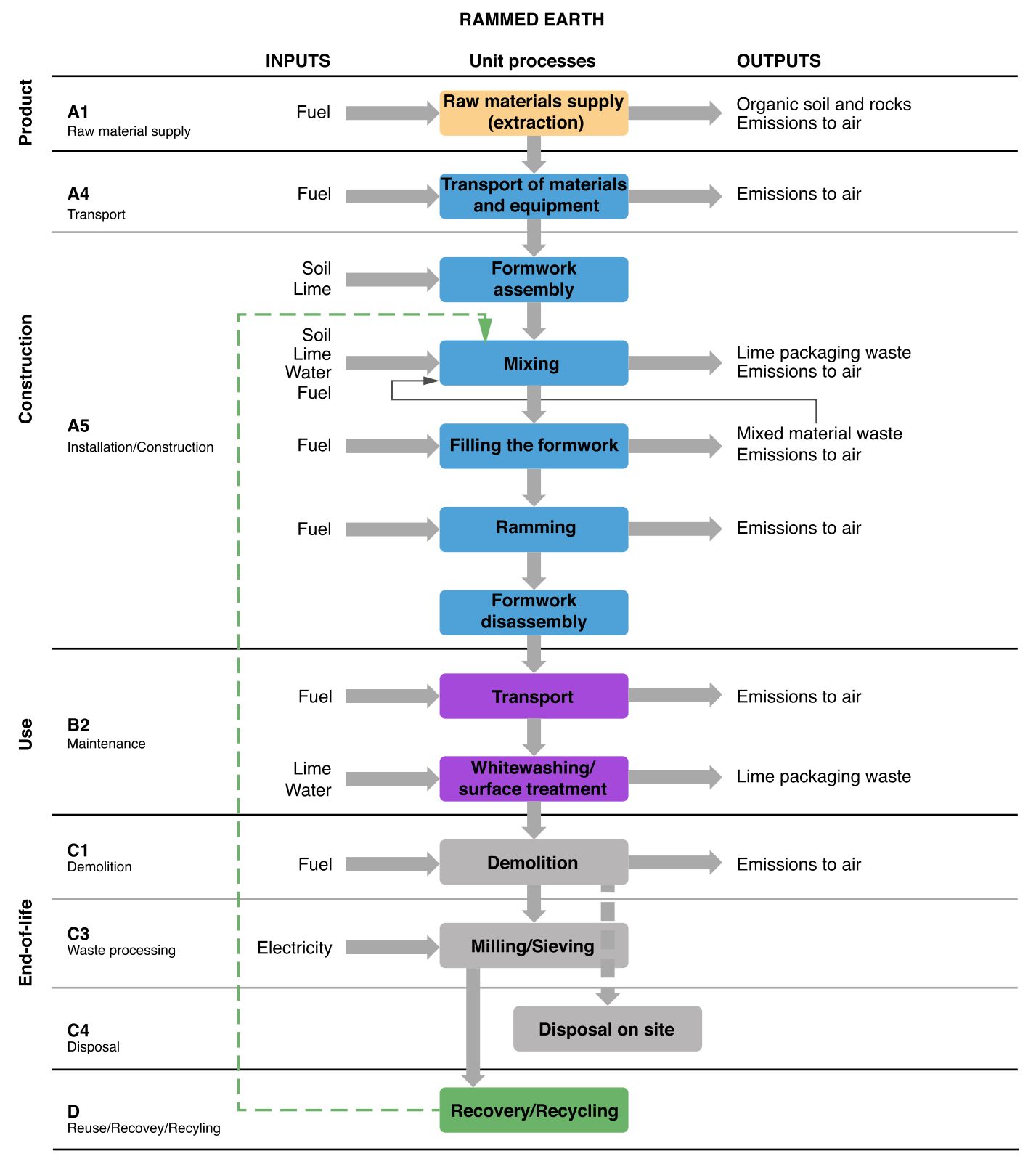

Fig. 4. Diagram of inputs and outputs of processes to build a rammed earth wall.

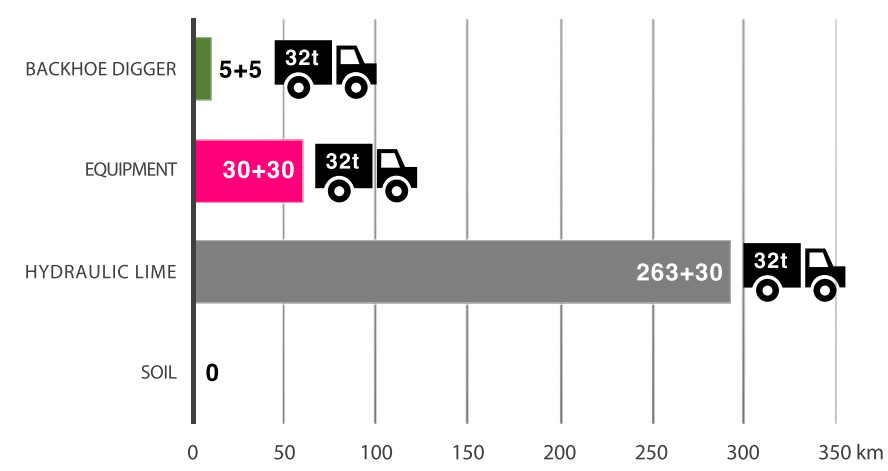

Fig. 5. Travelling distances and type of transportation for each material/product of the rammed earth construction process. g) Ramming - This process is carried out by workers using pneumatic rammers driven by a portable diesel-powered air compressor (fuel consumption of $6.8 \mathrm{l} / \mathrm{h}$, which is equivalent to $2.63 \mathrm{l} / \mathrm{m}^{3}$ of rammed earth).

h) Formwork disassembly - This process consists of disassembling the formwork and is mostly manual with the occasional use of the telescopic handler. After this process, the rammed earth wall is dried naturally.

\subsubsection{Use stage scenario}

2.4.2.2.1. Module B2 - Maintenance. In the Use stage, the company only provided data regarding the maintenance of the wall. As in the case of the CEB, the other modules of the 'Use Stage' were not considered. The following unitary processes compose this module:

a) Transport - this process includes the transportation of building products and equipment from headquarters to the building site, 
namely lime and some small equipment and objects. The type of transport used is usually a diesel-powered van.

b) Whitewashing - The whitewash is the most common maintenance procedure in this type of wall, but other types of surface maintenance are also applied, mainly when the wall surface is not covered by a finishing layer (e.g. render). The maintenance is usually carried out in 4-5 years interval but can be longer if, for example, the wall is protected from the rain. The whitewash procedure is equal to the one mentioned for the CEBs. The whitewash is applied manually, and no energy input is required in this process.

\subsubsection{End-of-life stage scenario}

2.4.2.3.1. Module C1 - Demolition. The demolition process of a rammed earth wall is very similar to a conventional wall. This process uses typically a diesel-powered backhoe digger or a miniexcavator with a hydraulic hammer, and occasionally it may be necessary to use manual demolition equipment such as jackhammers. The time required for the demolition process depends upon the type and size of the structure to be demolished. In this process, it is included the on-site sorting of the demolition waste.

2.4.2.3.2. Module $\mathrm{C} 3$ - Waste processing. In the case of rammed earth, waste processing is made on the building site. The process is simple and consists of crushing/milling the waste of the rammed earth wall (including renders, if applicable) to recover the material for a new product cycle. In this process, it is used an electrical jaw crusher. The resulting material is forwarded to the process of recovery/recycling (module D).

2.4.2.3.3. Module C4 - Disposal. In the demolition process, it is assumed that near $10 \%$ of the material is lost and $90 \%$ is recovered. Therefore, $10 \%$ of demolition waste is left in the building site. Since the product is mainly made from soil, it is possible to state that there is no significant impact from returning this material to the natural environment.

\subsubsection{Benefits and loads beyond the system boundary}

2.4.2.4.1. Module D - Recovery/Recycling. The process of recovery/recycling recovers the resulting material from waste processing (module C3) for a new product cycle. The material is forwarded to the mixing process (Module A3) to be reused in a new wall. The use of the recovered material has economic and environmental benefits and will not affect the functional performance of the new wall.

\subsubsection{Cut-off criteria}

In the assessment of the environmental impacts of a rammed earth wall, and based in the EN 15804 cut-off rules, the following unitary processes were excluded:

a) Internal transport and equipment for formwork assembly since the equipment is used in several processes almost simultaneously and in some cases just sporadically (as in the formwork assembly), the contribution of internal transport and equipment is difficult to quantify and, in some cases, negligible;

b) Manual work, as it does not cause impacts;

c) Environmental loads related to the construction of the industrial facilities and production of equipment;

d) Maintenance of building facilities and equipment - the impacts attributed to the maintenance of facilities and equipment were not considered since they are difficult to quantify and have a low contribution in life cycle inventory (LCI) (Frischknecht et al., 2007);

e) In the administrative services the office consumables (e.g. office paper and tonners) were excluded since there was no purchase record history.
Table 3

Life cycle inventory per declared unit ( $1 \mathrm{~m}^{3}$ of rammed earth wall).

\begin{tabular}{lll}
\hline Inputs & Units & $1 \mathrm{~m}^{3}$ Rammed earth \\
\hline Soil & $\mathrm{kg}$ & $1.98 \mathrm{E}+03$ \\
Lime & $\mathrm{kg}$ & $3.27 \mathrm{E}+01$ \\
Water & $\mathrm{L}$ & $1.56 \mathrm{E}+02$ \\
Electricity & $\mathrm{kWh}$ & $1.59 \mathrm{E}+00$ \\
Fuel & $\mathrm{MJ}$ & $2.56 \mathrm{E}+02$ \\
Transport & ton.km & $1.70 \mathrm{E}+01$ \\
\hline Outputs & & \\
\hline Waste soil (gravel, etc.) & $\mathrm{kg}$ & $9.89 \mathrm{E}+01$ \\
Water (drying process) & $\mathrm{L}$ & $8.92 \mathrm{E}+01$ \\
\hline
\end{tabular}

f) The transport of employees to the construction site. Since it is difficult to determine the time required for the construction, the number of trips necessary to build the rammed earth walls were not considered.

\subsubsection{Life cycle inventory}

In the Product and Construction stages, specific data such as physical materials and quantities, type of equipment used, extraction capacity, the time required to mix and to pour into the formwork, fuel consumption of the portable air compressor, amount of waste and billing values were provided by the company. The company also provided the average distance between the company headquarters and the construction site and the type of transportation used.

The fuel and electricity used by the equipment in processes like extraction, mixing and lifting, take into consideration manufacturers technical sheets or data provided by them.

The inventory data regarding transportation, consumed fuel and electricity and production of hydraulic lime are based on the generic life cycle inventory Ecoinvent v3.3 database.

The data regarding transport vehicles, fuel, electricity, water and hydraulic lime, considered the processes predefined in SimaPro and Ecoinvent database. Table 3 presents the inputs and outputs to build $1 \mathrm{~m}^{3}$ of rammed earth wall. Fig. 6 shows the raw materials flow to build a rammed earth wall with $1 \mathrm{~m}^{3}$ (Product and Construction Stages).

\subsubsection{Allocation procedures}

As mentioned before, the business activity of the company covers diverse types of construction works. Thus, as in the assessment of CEBs, a financial allocation was used to carry out the calculation, i.e., a percentage of the revenue generated by each activity. The allocation was used to estimate the environmental loads resulting from the annual consumption of electricity and water in the company headquarters that can be attributed to the rammed earth construction works. Data from the year 2016 was used.

\section{LCA and discussion of results}

In the following paragraphs, is presented the LCA of earthen materials. The analysis is divided into two parts. The first part is focused on the LCA of CEB and rammed earth materials, based on their respective declared units. Then, to highlight potential environmental advantages of using local earthen materials in relation to conventional materials, a comparative LCA is carried out based on a functional unit of $1 \mathrm{~m}^{2}$ of a wall. 


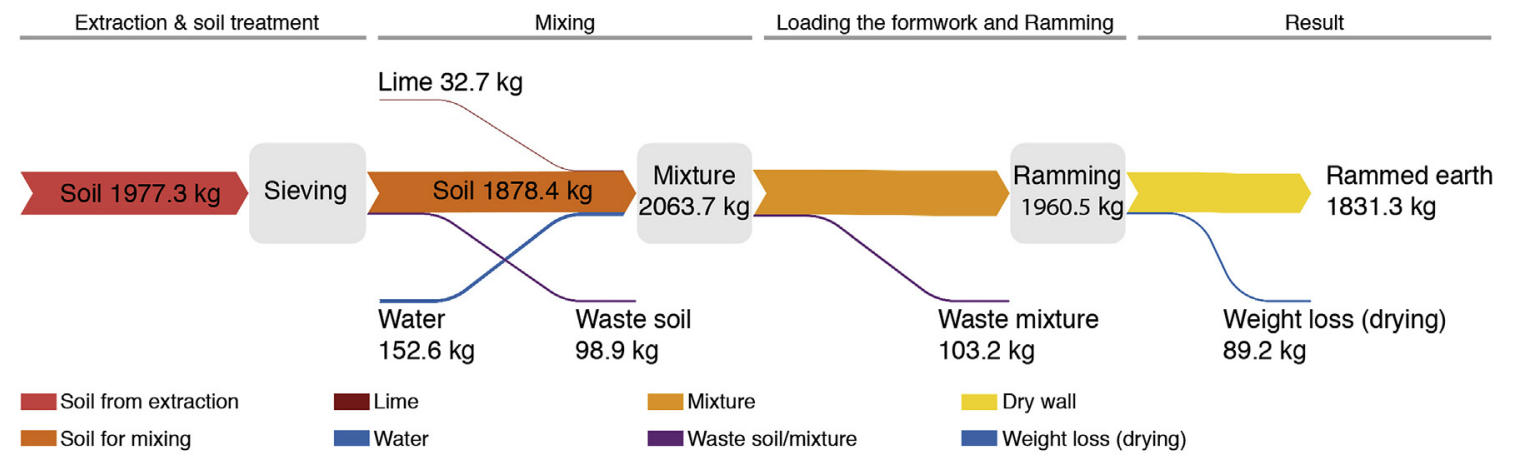

Fig. 6. Diagram of raw materials flow per declared unit $\left(1 \mathrm{~m}^{3}\right.$ of rammed earth wall).

\subsection{Compressed earth blocks}

\subsubsection{Environmental impacts}

Table 4 presents the environmental impacts related to the product stage (cradle-to-gate) of the compressed earth blocks. To understand the dimension of the environmental impacts associated with each module, the contribution of each module to the overall impact is illustrated in Fig. 7. From the analysis of the results, it is possible to verify that modules A2 and A3 are the ones that most contribute to the potential impacts (Fig. 7). In the ADP_ff category, modules A2 and A3 have almost the same contribution. In categories as ADP_elements and ODP, the module A2 has the highest weight. On the other side, in categories as GWP, POCP, AP and EP, it is the module $\mathrm{A} 3$ that has the highest contribution.

Although it is relevant to understand the contribution of each information module in each impact category, it is also important to identify the processes that contribute the most to the impacts within each module, in order to allow future improvements. Fig. 8 identifies the processes/products which cause more impacts in each module. During the Product Stage, it is possible to verify that the processes with the highest impacts, more than $50 \%$, in each module are the same for all environmental impact categories. In module A1, the extraction of soil using a backhoe digger has the highest impacts. In module $A 2$, the transport of soil from the extraction site to the manufacturing facility represents almost all the impacts associated with this module. Finally, in module A3 was expected that processes such as the mechanical processing of the soil (crushing, sieving and mixing) and the pressing process would have the highest weight in impacts, but results show that it is the addition of hydraulic lime that contributes to more than $60 \%$ of the value of all impact categories. Although with a lower contribution, the processes of mixing (using a diesel-powered concrete mixer) and pressing also stand out in some categories. The process of pressing in categories such as ADP_elements and POPC represents around $10 \%$, while the mixing process (concrete mixer) has some importance in more categories, namely, GWP ( $\approx 5 \%)$, ADP_ff ( $\approx 10 \%)$, ODP ( $\approx 20 \%), \mathrm{AP}(\approx 15 \%)$ and $\mathrm{EP}(\approx 15 \%)$.

\subsubsection{Embodied energy}

Table 5 presents the total embodied energy of 1 CEB. From the analysis of the results (Table 5 and Fig. 9), it is possible to verify that module A3 has the highest contribution in the total embodied energy, followed by module A2.

As verified in the assessment of environmental impacts, three processes represent more than $60 \%$ of the total energy used in each module (Fig. 10). In module A1, the process with the highest use of energy is the extraction of soil using a backhoe digger; in module A2, is the process related to the transport of soil; and in module A3 is the addition of hydraulic lime to the mix. Thus, in A3 the use of lime as stabiliser represents higher contribution to the total embodied energy than all the mechanical processes to obtain a CEB. The processes of mixing (concrete mixer) and pressing represent a contribution of approximately $10 \%$ each.

\subsection{Rammed earth}

\subsubsection{Environmental impacts}

As mentioned in previous sections, the construction process of rammed earth walls is entirely made on site, and therefore, the 'Construction Stage' also had to be considered. Table 6 presents the environmental impacts for each category. To understand the percentage of the environmental impacts associated with each module, the contribution of each module to the overall impact is illustrated in Fig. 11.

From the analysis of the results, module A5 (Construction) stands out by contributing most to all categories. Once the "material" is produced/built on site, the number of manufacturing processes and respective environmental load are concentrated in this module. Regarding the other modules, A1 (Raw material supply) and A4 (Transport), they have a similar weight (below 10\%) in almost all categories. The exception is made to the category ADP_elements where module A4 weights more than $35 \%$. In categories POPC, AP and EP, module A1 has a percentage slightly higher than module A4 but still below $10 \%$ of the total.

In order to understand which are the processes that have a

Table 4

Environmental impacts by declared unit (1 CEB).

\begin{tabular}{|c|c|c|c|c|c|}
\hline Impact category & Unit & Total & A1 - Raw material supply & A2 - Transport & A3 - Manufacturing \\
\hline Depletion of abiotic resources - mineral elements (ADP_elements) & $\mathrm{kg} \mathrm{Sb}$ eq & $5.72 \mathrm{E}-07$ & 5.32E-09 & $5.05 \mathrm{E}-07$ & $6.11 \mathrm{E}-08$ \\
\hline Depletion of abiotic resources - fossil fuels (ADP_ff) & MJ & $3.58 \mathrm{E}+00$ & $2.58 \mathrm{E}-01$ & $1.67 \mathrm{E}+00$ & $1.65 \mathrm{E}+00$ \\
\hline Global warming potential (GWP) & $\mathrm{kg} \mathrm{CO}_{2}$ eq & $3.88 \mathrm{E}-01$ & $1.68 \mathrm{E}-02$ & $1.07 \mathrm{E}-01$ & 2.63E-01 \\
\hline Ozone depletion (ODP) & $\mathrm{kg}$ CFC 11 eq & $3.46 \mathrm{E}-08$ & 1.92E-08 & 1.92E-08 & $1.23 \mathrm{E}-08$ \\
\hline Photochemical ozone creation (POPC) & $\mathrm{kg} \mathrm{C}_{2} \mathrm{H}_{4}$ eq & 4.92E-05 & 3.37E-06 & $1.86 \mathrm{E}-05$ & 2.72E-05 \\
\hline Acidification (AP) & $\mathrm{kg} \mathrm{SO}_{2} \mathrm{eq}$ & $1.24 \mathrm{E}-03$ & $1.28 \mathrm{E}-04$ & $4.10 \mathrm{E}-04$ & $7.01 \mathrm{E}-04$ \\
\hline Eutrophication (EP) & $\mathrm{kg}\left(\mathrm{PO}_{4}\right)^{3-}$ eq & $2.98 \mathrm{E}-04$ & 2.93E-05 & $9.70 \mathrm{E}-05$ & $1.72 \mathrm{E}-04$ \\
\hline
\end{tabular}




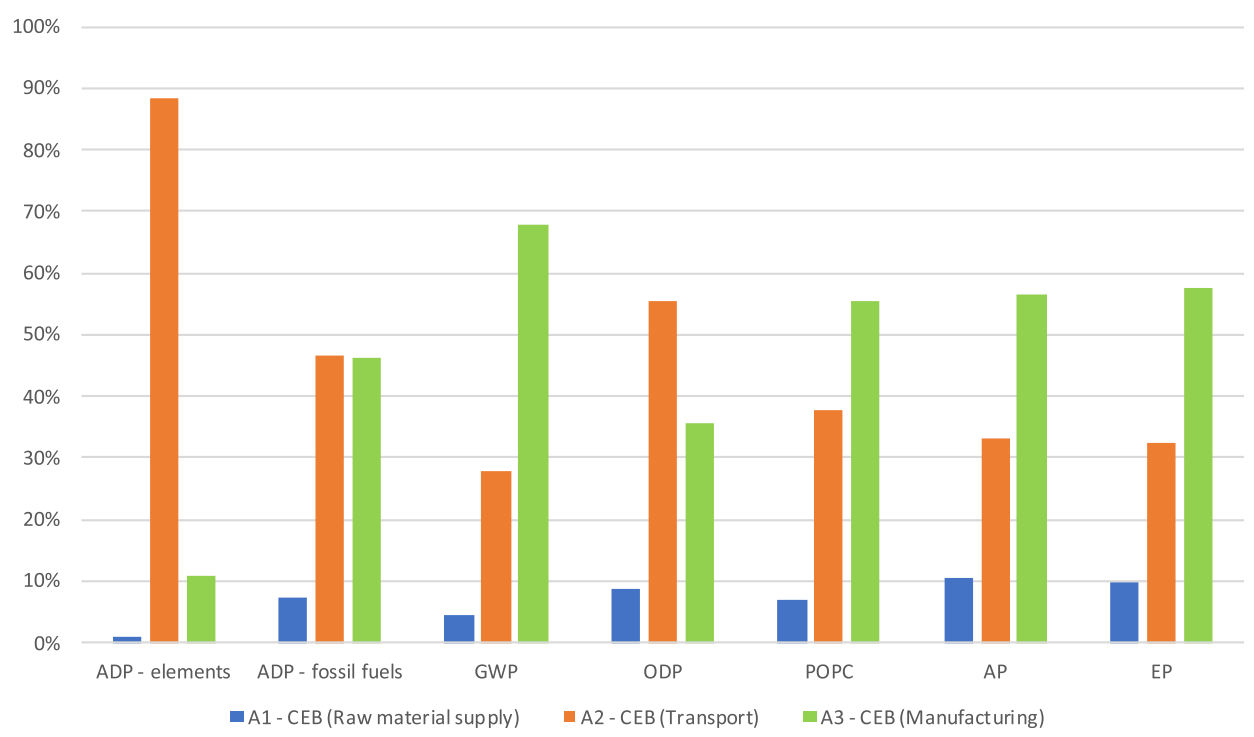

Fig. 7. Weight of the modules on each category of environmental impact, by declared unit (1 CEB).

higher contribution in each module, Fig. 12 presents the results for the several environmental impact categories. Regarding module A1, since the extraction of soil was the only process considered, it represents the total impacts of all categories. In module A4 (Transport), the transport of the hydraulic lime is the process with the highest contribution, almost 60\%, in all environmental impact categories. Lime represents only $3 \%$ of total rammed earth weight, but the addition of this stabiliser has a significant bearing on the impacts of this module, which could be reduced with the use of lime produced locally and if it is only used in situations in which the quality of the soil makes its use necessary.

In module A5, the addition of hydraulic lime to the mixture is responsible for the highest impacts in categories ADP_elements ( $\approx 45 \%)$ and GWP $(\approx 58 \%)$, but also has significant impacts in ADP_ff $(\approx 32 \%), \mathrm{ODP}(\approx 22 \%)$ and POPC $(\approx 36 \%), \mathrm{AP}(\approx 27 \%)$ and $\mathrm{EP}$ $(\approx 31 \%$ ) (Fig. 10). The use of the skid-steer loader in the mixing process and of the air compressor in the ramming process, more specifically the fuel consumed, are also responsible for considerable impacts in module A3. The use of the skid-steer loader has high impacts in categories ODP $(\approx 36 \%), \mathrm{AP}(\approx 33 \%)$ and $\mathrm{EP}(\approx 32 \%)$, but also has significant impacts in ADP_elements $(\approx 24 \%)$, ADP_ff ( $\approx 31 \%$ ), POPC $(\approx 29 \%$ ) and GWP $(\approx 19 \%$ ) (Fig. 10). The contribution of the air compressor has a similar profile, with values between 19 and $30 \%$, namely, ADP_elements $(\approx 24 \%)$, ADP_ff $(\approx 32 \%)$, GWP ( $\approx 19 \%)$, ODP ( $\approx 37 \%)$, POPC ( $\approx 29 \%)$ AP $(\approx 34 \%)$ and EP $(\approx 32 \%)$.

As already observed for the results of CEBs, the use of $3 \%$ of hydraulic lime as stabiliser represents a considerable share of the environmental impacts in almost all categories. The use of fuel in mechanical processes of mixing and ramming also has a significant share of impacts in module A5.

\subsubsection{Embodied energy}

Table 7 presents the total energy consumed to build $1 \mathrm{~m}^{3}$ of a rammed earth wall and the contribution of each information module (modules A1-A5).

From the analysis of the results, it is possible to verify that module A5 (Construction) has the highest contribution for the total embodied energy, with more than $80 \%$, following the trend verified in the environmental impact categories. Modules A1 and A4 have almost the same contribution, with less than $10 \%$ each (Table 7 and Fig. 13).
Likewise, the processes with higher energy use in each module were highlighted (Fig. 14). The analysis of the results is similar to the ones reported regarding the environmental impacts. In module A1, the extraction of soil using a backhoe digger is the only process and so the responsible for all the energy used in this module. In Module A4, the transport of hydraulic lime is responsible for almost $60 \%$ of the energy used in this module. As mentioned before, a small percentage of lime is responsible for considerable energy use. The other $40 \%$ are referred to the transport of the equipment, materials and other products. In Module A5, the processes with higher energy use are related to the fuel used by the air compressor and the skidsteer loader, and to the addition of hydraulic lime. The first two processes have almost the same contribution (around 30\%), being the contribution of the lime slightly higher (33\%) (Fig. 14). Once again, the lime has the highest contribution. Lime is the only product that is not produced locally, and that has an industriallybased production, and therefore its contribution to the embodied energy is significant. The embodied energy of the rammed earth produced by this company can be reduced if they find an alternative material or a producer with a less energy-intensive production system.

\subsection{Comparison of the environmental performance of different walls}

To address the potential environmental advantages of using local earthen materials/techniques in the Portuguese context, this section is devoted to a comparison between different types of external and partition walls, using earthen and conventional building materials. To compare the environmental performance of different building systems, in the same circumstances, the comparative analysis is made based on a functional unit of $1 \mathrm{~m}^{2}$ of a wall. Only the cradle-to-gate impacts are considered in this analysis. The transportation of materials was not considered since the travelling distance from the different manufacturers varies, and the potential impacts of this module could distort the comparison and the goal of the analysis.

For the external walls, the considered functional unit is $1 \mathrm{~m}^{2}$ of a wall that has the same U-value, according to technical data for the Portuguese context (Pina dos Santos and Matias, 2006; Pina dos Santos and Rodrigues, 2009). Therefore the external wall 


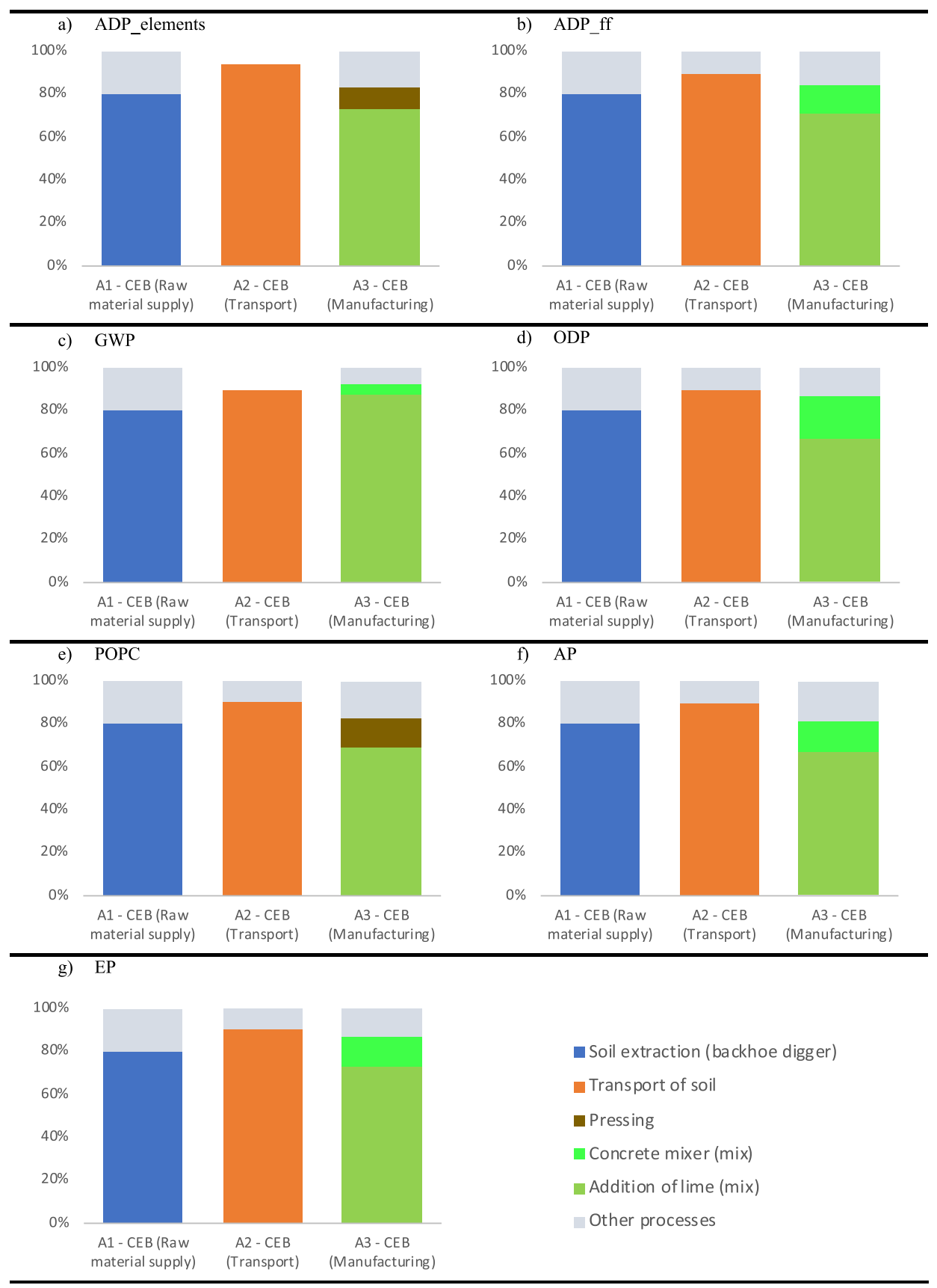

Fig. 8. Processes with the highest impacts by module and category of environmental impact by declared unit (1CEB).

Table 5

Total embodied energy by declared unit (1CEB).

\begin{tabular}{|c|c|c|c|c|c|}
\hline Total Energy & Unit & Total & A1 - Raw material supply & A2 - Transport & A3 - Manufacturing \\
\hline Embodied energy (EE, tot) & MJ & $3.94 \mathrm{E}+00$ & $2.61 \mathrm{E}-01$ & $1.74 \mathrm{E}+00$ & $1.93 \mathrm{E}+00$ \\
\hline
\end{tabular}

solutions considered have a similar $\mathrm{U}$-Value $\left(1,30 \mathrm{~W} /\left(\mathrm{m}^{2}{ }^{\circ} \mathrm{C}\right)\right)$ and are the following: i) Rammed Earth, without render, $\mathrm{R}=0,55$ $\left(\mathrm{m}^{2}{ }^{\circ} \mathrm{C}\right) / \mathrm{W}$, total thickness of $60 \mathrm{~cm}$; ii) Ceramic hollow brick $22 \mathrm{~cm}$, $\mathrm{R}=0,52\left(\mathrm{~m}^{2}{ }^{\circ} \mathrm{C}\right) / \mathrm{W}$, considering mortar and render (sand and cement), total thickness of $26 \mathrm{~cm}$; iii) Lightweight concrete block $25 \mathrm{~cm}, \mathrm{R}=0,54\left(\mathrm{~m}^{2} .{ }^{\circ} \mathrm{C}\right) / \mathrm{W}$, considering mortar and render (sand and cement), total thickness of $29 \mathrm{~cm}$.
For indoor partitions, the functional unit is $1 \mathrm{~m}^{2}$ of a wall that satisfies the national functional requirements for a partition wall inside a dwelling. Thus, the partition solutions considered are the following: i) CEB, considering mortar (lime and soil) without render, total thickness of $15 \mathrm{~cm}$; ii) Ceramic hollow brick $11 \mathrm{~cm}$, considering cement mortar in the joints and cement render as finishing layer, with a total thickness of $15 \mathrm{~cm}$; iii) Concrete block 


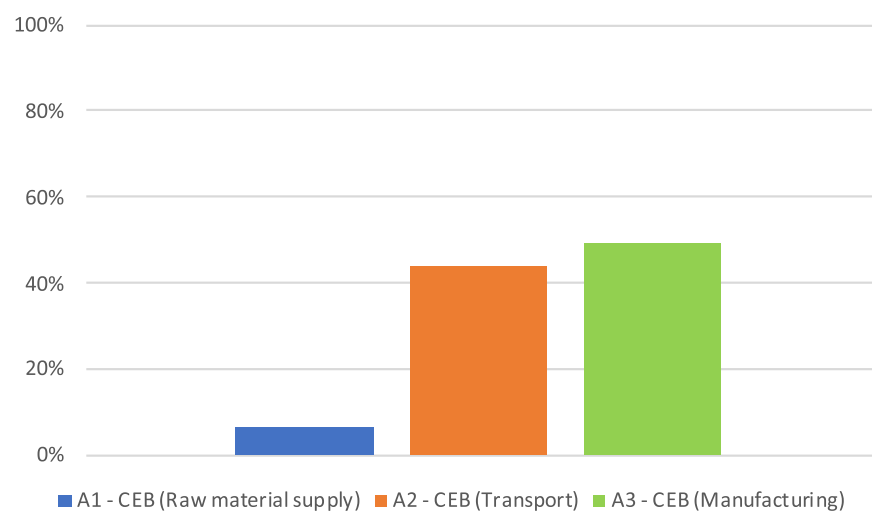

Fig. 9. The contribution of each module to the total embodied energy by declared unit (1 CEB).

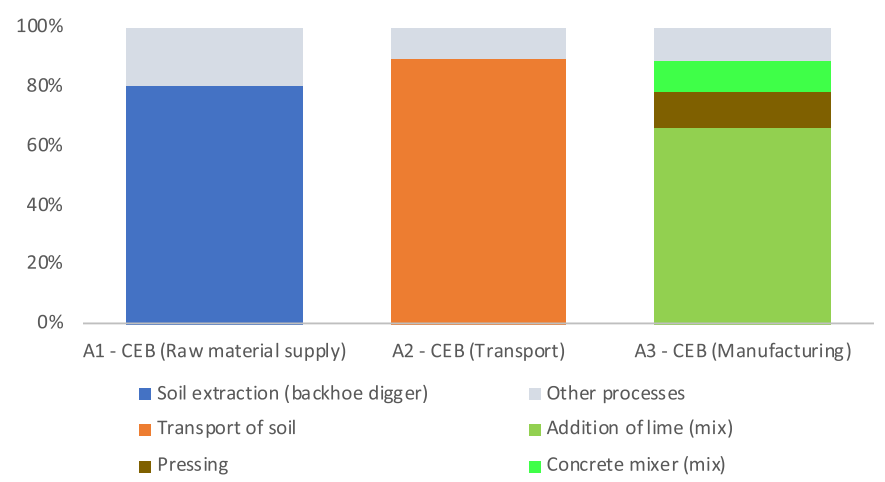

Fig. 10. Processes of each module that contribute the most to the embodied energy of a declared unit (1CEB).
$10 \mathrm{~cm}$, considering joints mortar and render (cement mortar), with a total thickness of $14 \mathrm{~cm}$. The calculation of the environmental impacts of the cement mortar was based on the generic inventory data from the Ecoinvent v3.3 database.

The inventory of materials used in the different wall solutions is presented in Tables 8 and 9.

From the analysis of the results, it is possible to verify that earthen materials have the best performance by far, both in environmental categories and embodied energy (Tables 10 and 11 and Figs. 15 and 16). In some environmental categories, the differences are not higher due to the weight of earthen solutions that is considerably higher than conventional building systems (except for ODP and AP in which rammed earth has equal or slightly higher impacts than conventional solutions). However, the weight of these solutions emphasises the low impacts and embodied energy and cannot be seen as a disadvantage, since earthen materials are acknowledged by their thermal and hygroscopic inertia that has benefits in stabilising indoor relative humidity and air temperature.

Therefore, when compared with industrially-produced materials, earthen materials have considerably lower environmental impacts and embodied energy, being an alternative for sustainable building. Moreover, and although it was not quantified, the potential of earthen materials to close the loop of materials and to be recovered and used in a new product cycle, with the same function, must be highlighted. Their low processing is an advantage since the waste treatment processes to recover the material are the same or similar to the ones considered to prepare raw materials. As an example of comparison, a brick wall does not have the same potential for being recovered/reused. The final disposal process for ceramic bricks after demolition consists in being used as filler material in the base of buildings or roads or landfilled as inert waste, as mentioned in the study of Almeida et al. (2015) for the

Table 6

Environmental impacts by declared unit ( $1 \mathrm{~m}^{3}$ of rammed earth wall).

\begin{tabular}{|c|c|c|c|c|c|}
\hline Impact category & Unit & Total & A1 - Raw material supply & A4 - Transport & A5- Construction \\
\hline Depletion of abiotic resources - mineral elements (ADP_elements) & $\mathrm{kg} \mathrm{Sb} \mathrm{eq}$ & $2.15 \mathrm{E}-05$ & $1.01 \mathrm{E}-06$ & 7.63E-06 & $1.29 \mathrm{E}-05$ \\
\hline Depletion of abiotic resources - fossil fuels (ADP_ff) & MJ & $5.71 \mathrm{E}+02$ & $4.88 \mathrm{E}+01$ & $4.43 \mathrm{E}+01$ & $4.78 \mathrm{E}+02$ \\
\hline Global warming potential (GWP) & $\mathrm{kg} \mathrm{CO} 2 \mathrm{eq}$ & $4.75 \mathrm{E}+01$ & $3.18 \mathrm{E}+00$ & $2.76 \mathrm{E}+00$ & $4.16 \mathrm{E}+01$ \\
\hline Ozone depletion (ODP) & $\operatorname{kg~CFC~} 11 \mathrm{eq}$ & $6.00 \mathrm{E}-06$ & $5.82 \mathrm{E}-07$ & $5.24 \mathrm{E}-07$ & 4.90E-06 \\
\hline Photochemical ozone creation (POPC) & $\mathrm{kg} \mathrm{C}_{2} \mathrm{H}_{4}$ eq & $7.91 \mathrm{E}-03$ & $6.39 \mathrm{E}-04$ & $4.53 \mathrm{E}-04$ & $6.82 \mathrm{E}-03$ \\
\hline Acidification (AP) & $\mathrm{kg} \mathrm{SO}_{2} \mathrm{eq}$ & $2.58 \mathrm{E}-01$ & $2.42 \mathrm{E}-02$ & $1.08 \mathrm{E}-02$ & $2.23 \mathrm{E}-01$ \\
\hline Eutrophication (EP) & $\mathrm{kg}\left(\mathrm{PO}_{4}\right)^{3-}$ eq & $6.12 \mathrm{E}-02$ & $5.56 \mathrm{E}-03$ & $2.43 \mathrm{E}-03$ & $5.32 \mathrm{E}-02$ \\
\hline
\end{tabular}

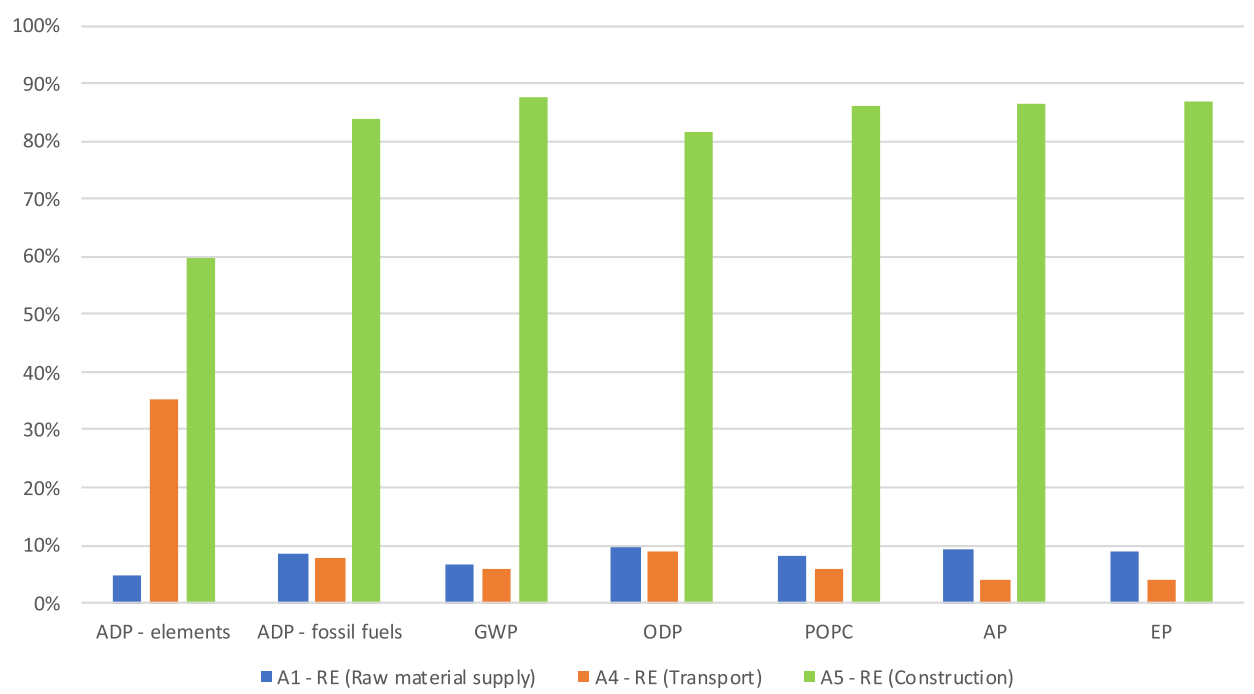

Fig. 11. Weight of the modules on each category of environmental impact, by declared unit ( $1 \mathrm{~m}^{3}$ of rammed earth wall). 


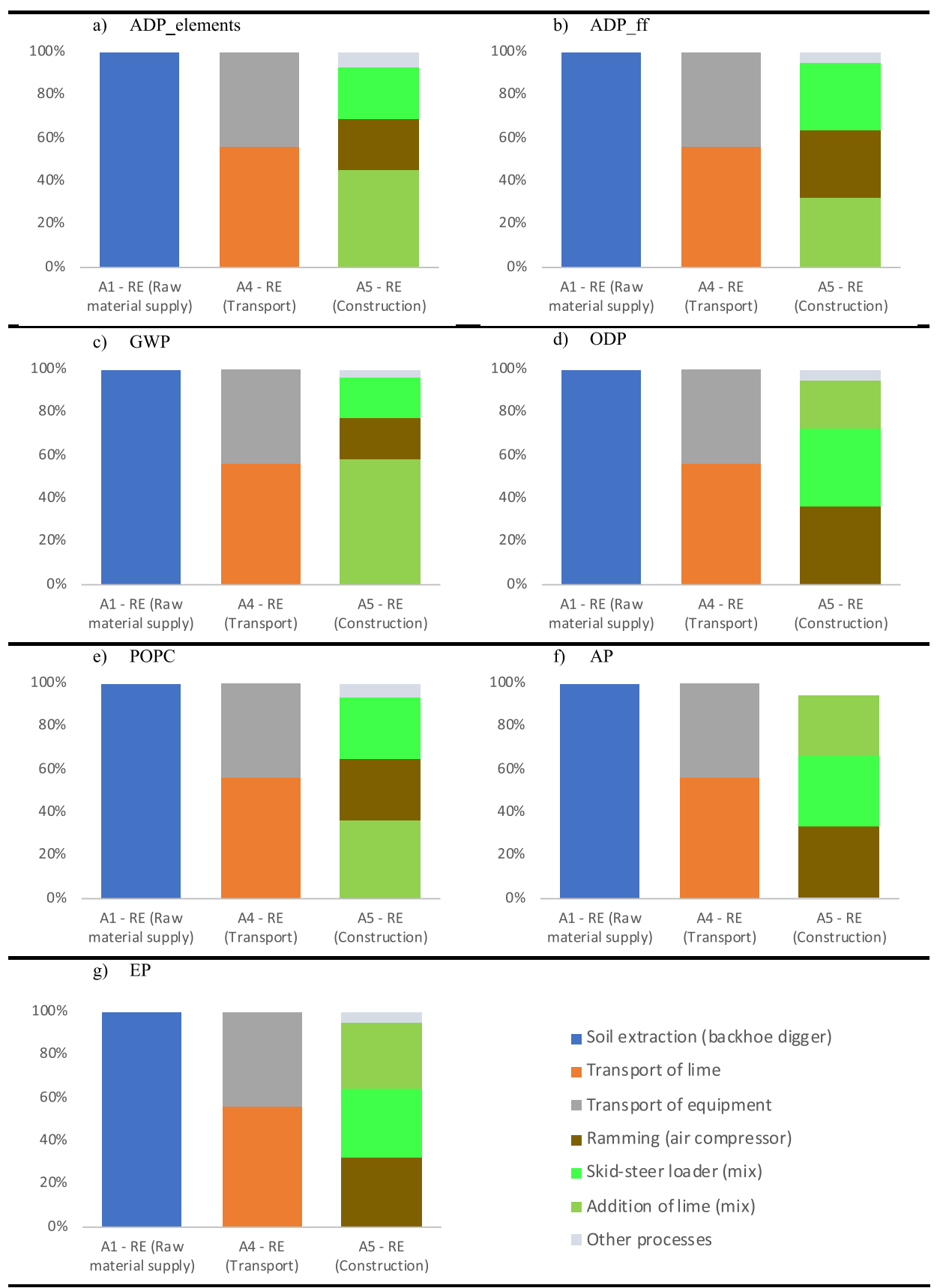

Fig. 12. Processes with the highest impacts by module and category of environmental impact by declared unit ( $1 \mathrm{~m}^{3}$ of rammed earth wall).

Table 7

Total embodied energy by declared unit $\left(1 \mathrm{~m}^{3}\right.$ of rammed earth wall).

\begin{tabular}{|c|c|c|c|c|c|}
\hline Total Energy & Unit & Total & A1 - Raw material supply & A4 - Transport & A5 - Construction \\
\hline Embodied energy (EE, tot) & MJ & $5.96 \mathrm{E}+02$ & $4.95 \mathrm{E}+01$ & $4.61 \mathrm{E}+01$ & $5.00 \mathrm{E}+02$ \\
\hline
\end{tabular}

Portuguese context. So, there is a quality lost in the original material that cannot be recovered, and the demolition waste has a limited reuse potential.

\section{Conclusions}

The life cycle assessment of earthen materials, in the Portuguese context, presented in this paper is a contribution to understanding the potential of these materials in current construction and more widely, in the scope of sustainable buildings.

Concerning compressed earth blocks, it was possible to verify that the modules of Transport (A2) and Manufacturing (A3) are the ones that most contribute to the environmental impacts and embodied energy. In module A2, the transport of soil represents more than $80 \%$ in all impact categories. Thus, choosing a closer extraction site will contribute to reducing the impacts of 


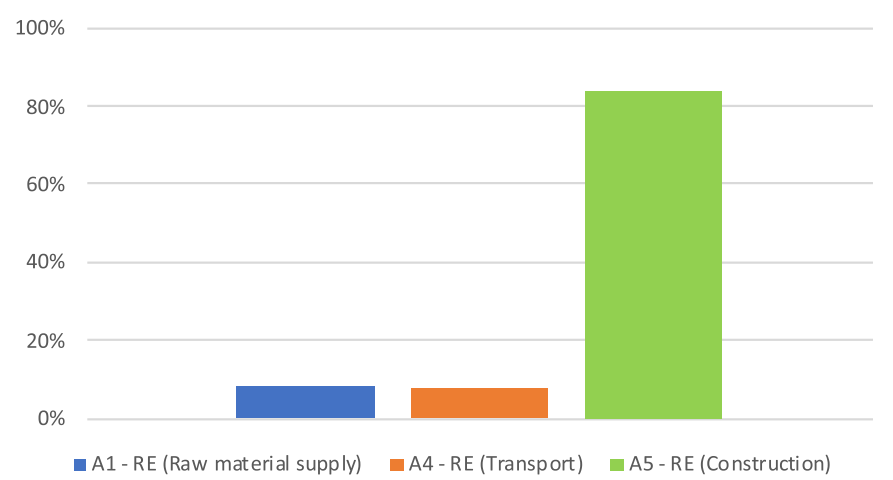

Fig. 13. The contribution of each module to the total embodied energy by declared unit ( $1 \mathrm{~m}^{3}$ of rammed earth wall).

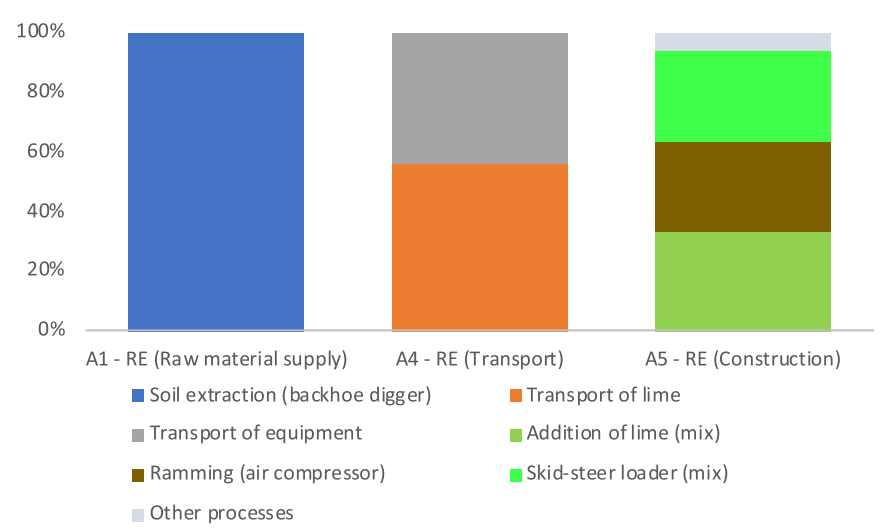

Fig. 14. Processes with highest embodied energy by module and by declared unit $\left(1 \mathrm{~m}^{3}\right.$ of rammed earth wall). transportation. In module $\mathrm{A} 3$, the addition of hydraulic lime is the process with more impact, representing more than $60 \%$ in all categories.

In the case of rammed earth, results show that the environmental impacts and embodied energy are above all related to the processes of module A5 (above 60\% in all categories. The fact of the material is produced/built on site explains this concentration and the processes related to extraction (A1) and transports (A4) have a small contribution (around 10\%). The use of hydraulic lime represents considerable impacts both in modules A4 (Transport) and A5 (Construction). In the latter, the use of fuel for the equipment is also responsible for considerable impacts in all categories and represents $60 \%$ of the total embodied energy.

For both materials, the use of lime, even in small percentages, stood out as having a high contribution to the environmental impacts and embodied energy. This is the only product used that is not produced locally, and that has an industrially-based production. The impacts of both materials could be reduced if the lime could be locally sourced, or if an alternative material with a less energyintensive production system could be used, and if the amount of energy used could be reduced or offset through the use of more energy from renewable sources.

Even with the introduction of some mechanised processes, which significantly increased productivity and allowed to homogenise the quality of the final product, the earthen materials studied continue to be low processing materials. This is visible when earthen materials are compared with industrially-produced materials since they have a significantly higher environmental performance, with lower environmental impacts and embodied energy. Taking as an example two categories usually mentioned as important in the context of buildings, i.e., GWP and Embodied Energy, $1 \mathrm{~m}^{2}$ wall of Rammed Earth and CEB have around a half of carbon emissions and embodied energy than ceramic brick or concrete

Table 8

Data inventory of the materials used in the different external walls per functional unit $\left(1 \mathrm{~m}^{2}\right)$.

\begin{tabular}{|c|c|c|c|c|}
\hline Inputs & Units & Rammed earth $(60 \mathrm{~cm})$ & Ceramic brick $(26 \mathrm{~cm})$ & Lightweight concrete block $(29 \mathrm{~cm})$ \\
\hline Rammed earth & $\mathrm{kg}$ & $1.10 \mathrm{E}+03$ & - & - \\
\hline Ceramic brick & $\mathrm{kg}$ & - & $1.19 \mathrm{E}+02$ & - \\
\hline Lightweight concrete & $\mathrm{kg}$ & - & - & $1.12 \mathrm{E}+02$ \\
\hline Mortar & $\mathrm{kg}$ & - & $1.10 \mathrm{E}+02$ & $1.07 \mathrm{E}+02$ \\
\hline
\end{tabular}

Table 9

Data inventory of the materials used in the different partition walls per functional unit $\left(1 \mathrm{~m}^{2}\right)$.

\begin{tabular}{|c|c|c|c|c|}
\hline nputs & Units & CEB $(15 \mathrm{~cm})$ & Ceramic brick $(15 \mathrm{~cm})$ & Concrete block $(14 \mathrm{~cm})$ \\
\hline CEB & $\mathrm{kg}$ & $2.46 \mathrm{E}+02$ & - & - \\
\hline Earth mortar & $\mathrm{kg}$ & $4.45 \mathrm{E}+01$ & - & - \\
\hline Ceramic brick & $\mathrm{kg}$ & - & $6.36 \mathrm{E}+01$ & - \\
\hline Concrete block & $\mathrm{kg}$ & - & - & $9.06 \mathrm{E}+01$ \\
\hline Mortar & $\mathrm{kg}$ & - & $9.25 \mathrm{E}+01$ & $8.86 \mathrm{E}+01$ \\
\hline
\end{tabular}

Table 10

Assessment of the environmental performance and embodied energy of $1 \mathrm{~m}^{2}$ of different external walls.

\begin{tabular}{|c|c|c|c|c|}
\hline Impact category & Unit & Rammed earth $(60 \mathrm{~cm})$ & Ceramic brick $(26 \mathrm{~cm})$ & Lightweight concrete block $(29 \mathrm{~cm})$ \\
\hline Depletion of abiotic resources - mineral elements (ADP_elements) & $\mathrm{kg} \mathrm{Sb} \mathrm{eq}$ & $1.29 \mathrm{E}-05$ & $8.21 \mathrm{E}-05$ & $9.56 \mathrm{E}-05$ \\
\hline Depletion of abiotic resources - fossil fuels (ADP_ff) & MJ & $3.43 \mathrm{E}+02$ & $4.61 \mathrm{E}+02$ & $6.04 \mathrm{E}+02$ \\
\hline Global warming potential (GWP) & $\mathrm{kg} \mathrm{CO} 2$ eq & $2.85 \mathrm{E}+01$ & $5.74 \mathrm{E}+01$ & $8.26 \mathrm{E}+01$ \\
\hline Ozone depletion (ODP) & $\mathrm{kg} \mathrm{CFC} 11 \mathrm{eq}$ & $3.60 \mathrm{E}-06$ & 3.87E-06 & $2.80 \mathrm{E}-06$ \\
\hline Photochemical ozone creation (POPC) & $\mathrm{kg} \mathrm{C}_{2} \mathrm{H}_{4}$ eq & 4.74E-03 & $9.26 \mathrm{E}-03$ & $1.97 \mathrm{E}-02$ \\
\hline Acidification (AP) & $\mathrm{kg} \mathrm{SO}_{2}$ eq & $1.55 \mathrm{E}-01$ & $1.63 \mathrm{E}-01$ & 4.19E-01 \\
\hline Eutrophication (EP) & $\mathrm{kg}\left(\mathrm{PO}_{4}\right)^{3-}$ eq & 3.67E-02 & $4.53 \mathrm{E}-02$ & $8.63 E-02$ \\
\hline Embodied energy (EE, tot) & MJ & $3.58 \mathrm{E}+02$ & $5.40 \mathrm{E}+02$ & $7.23 \mathrm{E}+02$ \\
\hline
\end{tabular}


Table 11

Assessment of the environmental performance and embodied energy of $1 \mathrm{~m}^{2}$ of different internal partition walls.

\begin{tabular}{|c|c|c|c|c|}
\hline Impact category & Unit & CEB $(15 \mathrm{~cm})$ & Ceramic brick $(15 \mathrm{~cm})$ & Concrete block $(14 \mathrm{~cm})$ \\
\hline Depletion of abiotic resources - mineral elements (ADP_elements) & $\mathrm{kg} \mathrm{Sb} \mathrm{eq}$ & 2.34E-05 & $4.90 \mathrm{E}-05$ & $4.95 \mathrm{E}-05$ \\
\hline Depletion of abiotic resources - fossil fuels (ADP_ff) & MJ & $1.50 \mathrm{E}+02$ & $2.96 \mathrm{E}+02$ & $2.05 \mathrm{E}+02$ \\
\hline Global warming potential (GWP) & $\mathrm{kg} \mathrm{CO}{ }_{2}$ eq & $1.66 \mathrm{E}+01$ & $3.91 \mathrm{E}+01$ & $3.20 \mathrm{E}+01$ \\
\hline Ozone depletion (ODP) & $\mathrm{kg}$ CFC 11 eq & $1.44 \mathrm{E}-06$ & $2.40 \mathrm{E}-06$ & $1.54 \mathrm{E}-06$ \\
\hline Photochemical ozone creation (POPC) & $\mathrm{kg} \mathrm{C}_{2} \mathrm{H}_{4}$ eq & 2.07E-03 & $6.08 \mathrm{E}-03$ & 4.60E-03 \\
\hline Acidification (AP) & $\mathrm{kg} \mathrm{SO}_{2} \mathrm{eq}$ & $5.21 \mathrm{E}-02$ & $1.13 \mathrm{E}-01$ & $1.02 \mathrm{E}-01$ \\
\hline Eutrophication (EP) & $\mathrm{kg}\left(\mathrm{PO}_{4}\right)^{3-}$ eq & $1.26 \mathrm{E}-02$ & $3.09 \mathrm{E}-02$ & $2.82 \mathrm{E}-02$ \\
\hline Embodied energy (EE, tot) & MJ & $1.65 \mathrm{E}+02$ & $3.49 \mathrm{E}+02$ & $2.45 \mathrm{E}+02$ \\
\hline
\end{tabular}

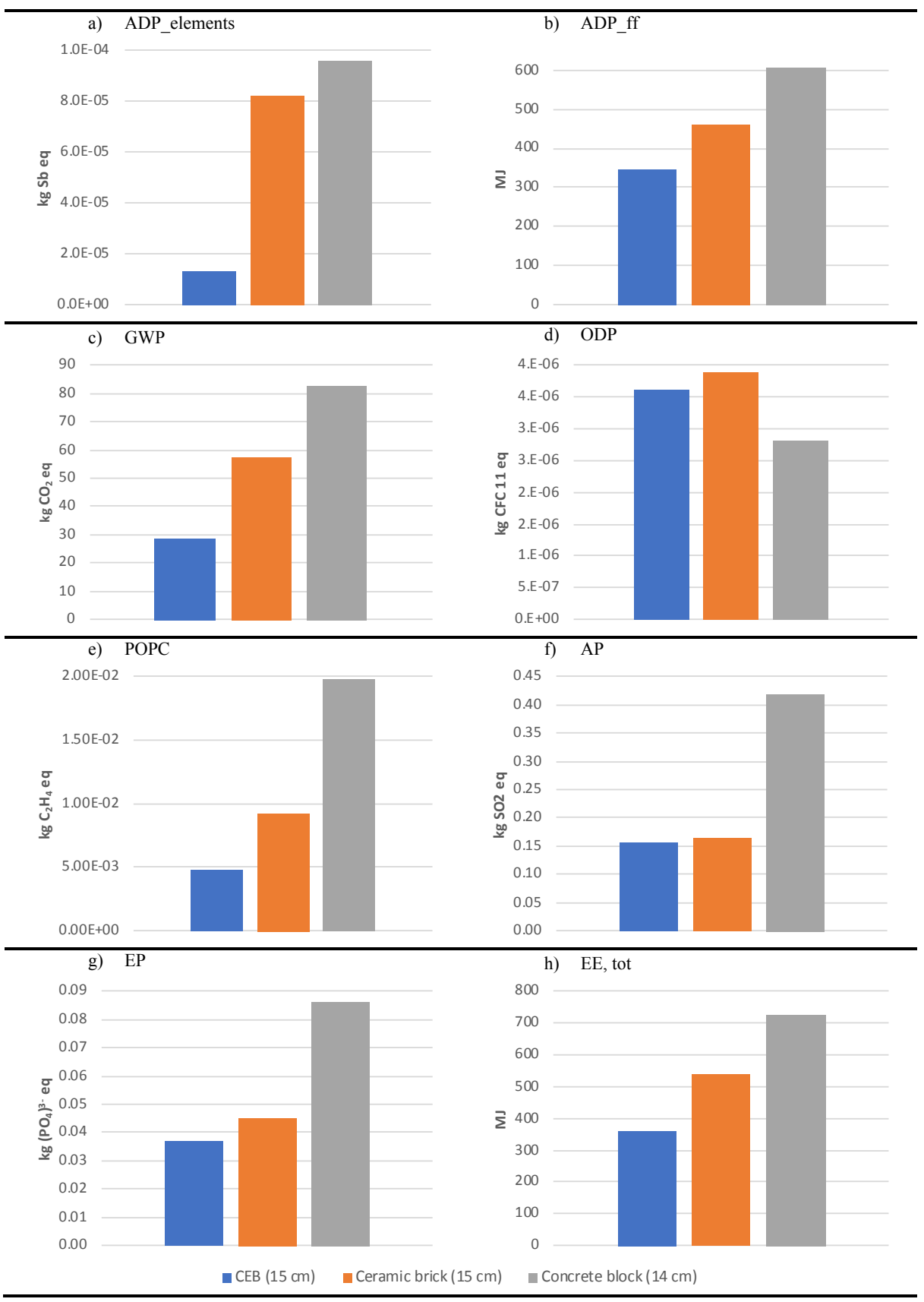

Fig. 15. Assessment of the environmental performance of $1 \mathrm{~m}^{2}$ of different external walls. 


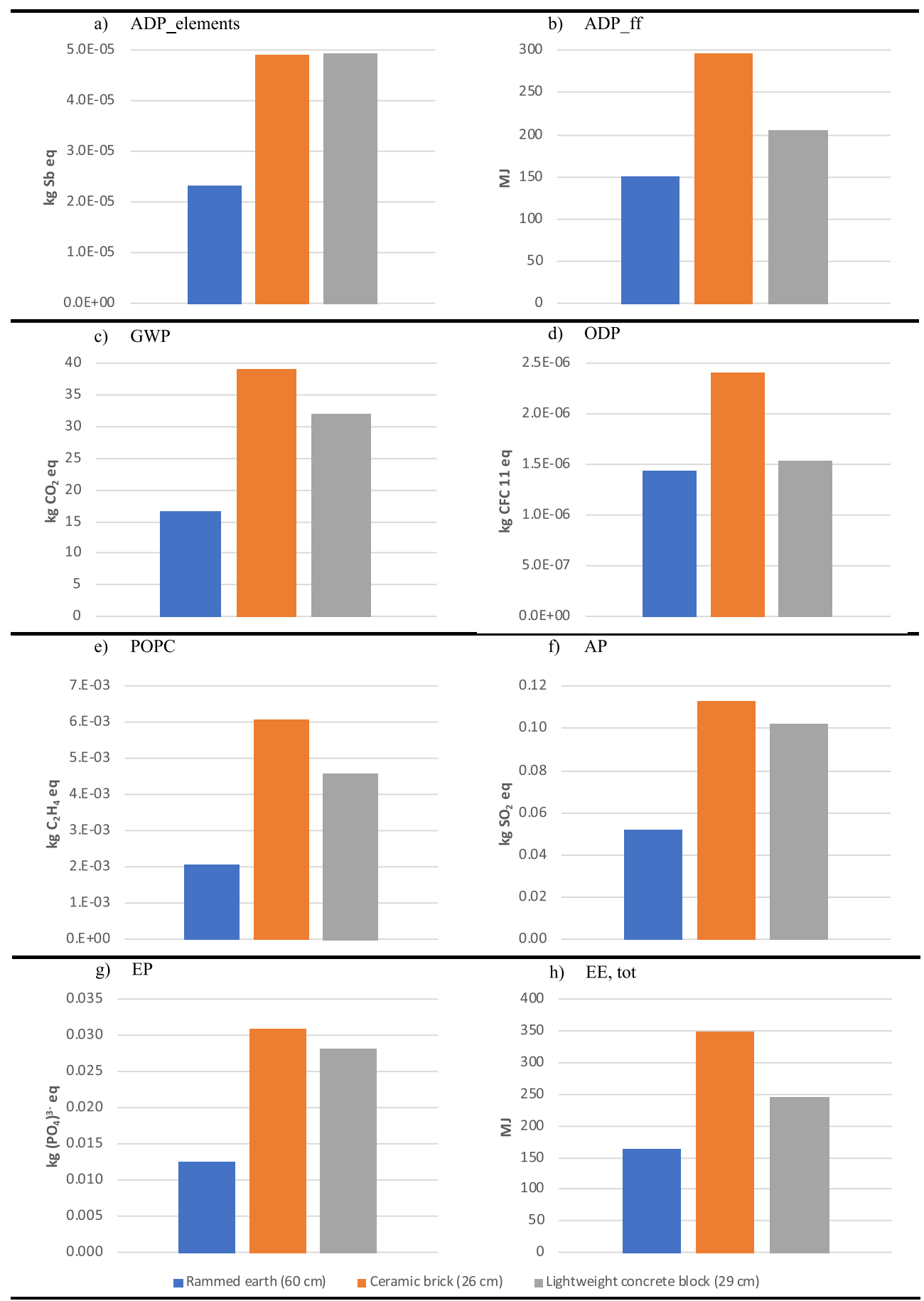

Fig. 16. Assessment of the environmental performance of $1 \mathrm{~m}^{2}$ of different internal partition walls.

block walls.

Taking into account the sourcing of materials, additional benefits (e.g. social and economic) may be achieved by using local-made materials. Since these materials are locally sourced and produced, its commercialisation out of the regions of origin, or where they are typically used, can undermine the environmental advantages presented in this paper. Therefore, more LCA studies on vernacular materials are needed to further understand their environmental performance, but also to allow transparent comparisons with other building materials. Additionally, it is perceptible that the impacts from the end-of-life of earthen materials can be lower than the impacts of conventional building materials since they can be easily recycled into a new material loop with the same function as the previous one or returned to the natural environment at a very small environmental cost. Nevertheless, more studies are needed to further assess the real contribution of these materials in the promotion of a circular built environment.

\section{Declarations of interest}

None. 


\section{Acknowledgments}

The authors would like to acknowledge the support granted by the FEDER funds through the Competitivity and Internationalization Operational Programme (POCI) and by national funds through FCT-Foundation for Science and Technology within the scope of the project with the reference POCI-01-0145-FEDER-029328, and of the Ph.D. grant with the reference $\mathrm{PD} / \mathrm{BD} / 113641 / 2015$, that were fundamental for the development of this study. The authors also wish to thank the construction company for providing the life cycle inventory data and helping this research work.

\section{References}

Aillapán, J., 2012. Analisis de Ciclo de Vida de Bloques de Tierra Comprimida. BTC Universidade de La Frontera.

Almeida, M.I., Dias, A.C., Demertzi, M., Arroja, L., 2015. Contribution to the development of product category rules for ceramic bricks. J. Clean. Prod. 92, 206-215. https://doi.org/10.1016/J.JCLEPRO.2014.12.073.

Arrigoni, A., Beckett, C., Ciancio, D., Dotelli, G., 2017. Life cycle analysis of environmental impact vs. durability of stabilised rammed earth. Constr. Build. Mater. 142, 128-136. https://doi.org/10.1016/j.conbuildmat.2017.03.066.

Bengtsson, J., Logie, J., 2015. Life cycle assessment of one-way and pooled pallet alternatives. Procedia CIRP 29, 414-419. In: https://doi.org/10.1016/j procir.2015.02.045.

Berge, B., 2009. The Ecology of Building Materials, second ed. Elsevier, Oxford. null. https://doi.org/10.1016/B978-1-85617-537-1.00014-7.

Cabeza, L.F., Barreneche, C., Miró, L., Morera, J.M., Bartolí, E., Inés Fernández, A. 2013. Low carbon and low embodied energy materials in buildings: a review. Renew. Sustain. Energy Rev. 23, 536-542. https://doi.org/10.1016/J.RSER.2013. 03.017.

CEN, 2012. EN 15804:2012+A1:2013 - Sustainability of Construction Works e Environmental Product Declarations e Core Rules for the Product Category of Construction Products.

Chandel, S.S., Sharma, V., Marwah, B.M., 2016. Review of energy efficient features in vernacular architecture for improving indoor thermal comfort conditions. Renew. Sustain. Energy Rev. 65, 459-477. https://doi.org/10.1016/j.rser.2016.07. 038.

Chel, A., Tiwari, G.N., 2009. Thermal performance and embodied energy analysis of a passive house - case study of vault roof mud-house in India. Appl. Energy 86 1956-1969. https://doi.org/10.1016/j.apenergy.2008.12.033.

Christoforou, E., Kylili, A., Fokaides, P.A., Ioannou, I., 2016. Cradle to site life cycle assessment (LCA) of adobe bricks. J. Clean. Prod. 112, 443-452. https://doi.org/ 10.1016/j.jclepro.2015.09.016.

Dabaieh, M., 2015. More than Vernacular: Vernacular Architecture between Past Tradition and Future Vision. Lund University (Media-Tryck), Lund.

DAPHabitat, n.d. DAPHabitat: published EPDs [WWW Document]. URL https:// daphabitat.pt/en_US/dap/dap-registadas/(accessed 10.25.2018).

Eco Platform, n.d. Eco Platform EPD list [WWW Document]. URL https://www.ecoplatform.org/list-of-all-eco-epd.html (accessed 10.26.2018).

EPD International $A B$, n.d. The international $E P D \circledR$ system: EPD database [WWW Document]. URL https://www.environdec.com/EPD-Search/(accessed 10.26.2018).

Fernandes, J., Mateus, R., Bragança, L., 2013. The potential of vernacular materials to the sustainable building design. In: Correia, M., Carlos, G., Rocha, S. (Eds.), Vernacular Heritage and Earthen Architecture: Contributions for Sustainable Development. CRC Press, Vila Nova da Cerveira, Portugal, pp. 623-629. https:// doi.org/10.1201/b15685.

Fernandes, Jorge, Mateus, R., Bragança, L., 2013. The contribute of using vernacular materials and techniques for sustainable building. In: Bragança, L., Pinheiro, M., Mateus, R. (Eds.), International Conference SB13 Portugal - Sustainable Building Contribution to Achieve the EU 20-20-20. Universidade Do Minho, Técnico Lisboa. iiSBE Portugal, Guimarães, pp. 269-278.

Fernandes, J., Pimenta, C., Mateus, R., Silva, S.M., Bragança, L., 2015. Contribution of Portuguese vernacular building strategies to indoor thermal comfort and occupants' perception. Buildings 5, 1242-1264. https://doi.org/10.3390/ buildings5041242.

Frischknecht, R., Jungbluth, N., Althaus, H.-J., Doka, G., Dones, R., Hischier, R., Hellweg, S., Nemecek, T., Rebitzer, G., Spielmann, M., 2007. Overview and Methodology. Final Report Ecoinvent Data v2.0, No . 1. Swiss Centre for Life Cycle Inventories, Dübendorf, $\mathrm{CH}$. Dübendorf.

Hamard, E., Cazacliu, B., Razakamanantsoa, A., Morel, J.-C., 2016. Cob, a vernacular earth construction process in the context of modern sustainable building. Build. Environ. 106, 103-119. https://doi.org/10.1016/J.BUILDENV.2016.06.009.

Ibáñez-Forés, V., Pacheco-Blanco, B., Capuz-Rizo, S.F., Bovea, M.D., 2016. Environmental Product Declarations: exploring their evolution and the factors affecting their demand in Europe. J. Clean. Prod. 116, 157-169. https://doi.org/10.1016/J. JCLEPRO.2015.12.078.

Ingwersen, W.W., Stevenson, M.J., 2012. Can we compare the environmental performance of this product to that one? An update on the development of product category rules and future challenges toward alignment. J. Clean. Prod. 24, 102-108. https://doi.org/10.1016/J.JCLEPRO.2011.10.040.

ISO, 2006a. ISO 14025: Environmental Labels and Declarations - Type III Environmental Declarations - Principles and Procedures (Geneva).

ISO, 2006b. ISO 14040: Environmental Management - Life Cycle Assessment Principles and Framework (Geneva).

ISO, 2006c. ISO 14044: Environmental Management - Life Cycle Assessment - Requirements and Guidelines (Geneva).

Jaquin, P.A., Augarde, C.E., Gerrard, C.M., 2008. Chronological description of the spatial development of rammed Earth techniques. Int. J. Archit. Herit. 2, 377-400. https://doi.org/10.1080/15583050801958826.

Leitão, D., Barbosa, J., Soares, E., Miranda, T., Cristelo, N., Briga-Sá, A., 2017. Thermal performance assessment of masonry made of ICEB's stabilised with alkaliactivated fly ash. Energy Build. 139, 44-52. https://doi.org/10.1016/J.ENBUILD. 2016.12.068.

Maza, F., 2012. Análisis del ciclo de vida de materiales de construcción convencionales y alternativos. Universidad Autónoma de San Luis Potosí, Mexico.

Melià, P., Ruggieri, G., Sabbadini, S., Dotelli, G., 2014. Environmental impacts of natural and conventional building materials: a case study on earth plasters. J. Clean. Prod. 80, 179-186. https://doi.org/10.1016/j.jclepro.2014.05.073.

Minke, G., 2006. Building with Earth: Design and Technology of a Sustainable Architecture (Birkhäuser, Basel).

Morel, J., Mesbah, A., Oggero, M., Walker, P., 2001. Building houses with local materials: means to drastically reduce the environmental impact of construction. Build. Environ. 36, 1119-1126. https://doi.org/10.1016/S0360-1323(00)00054-8.

Pereira, H., 2017. Desenvolvimento da Declaracão Ambiental do Produto (DAP) do Bloco de Terra Comprimida (BTC). University of Minho.

Pina dos Santos, C.A., Matias, L., 2006. ITE50 - Coeficientes de Transmissão Térmica de Elementos da Envolvente dos Edificios. Laboratório Nacional de Engenharia Civil/National Laboratory of Civil Engineering, Lisboa.

Pina dos Santos, C.A., Rodrigues, R., 2009. ITE54 - Coeficientes de Transmissão Térmica de Elementos Opacos da Envolvente dos Edificios. Laboratório Nacional de Engenharia Civil/National Laboratory of Civil Engineering, Lisboa.

Praseeda, K.I., Mani, M., Reddy, B.V.V., 2014. Assessing impact of material transition and thermal comfort models on embodied and operational energy in vernacular dwellings (India). Energy Procedia 54, 342-351. https://doi.org/10.1016/j. egypro.2014.07.277.

Ramesh, S., 2012. Appraisal of vernacular building materials and alternative technoligies for roofing and terracing options of embodied energy in buildings. Energy Procedia 14, 1843-1848. https://doi.org/10.1016/j.egypro.2011.12.1177.

Sanz-Calcedo, J.G., Luna, M.F., Soriano, R.C., 2012. Evaluation of the efficiency to use sustainable classical techniques on the modern construction. In: Amoêda, R., Mateus, R., Bragança, L., Pinheiro, C. (Eds.), BSA 2012: 1st International Conference on Building Sustainability Assessment. Greenlines Institute for Sustainable Development, Porto, pp. 667-675.

Sassi, P., 2006. Strategies for Sustainable Architecture. Taylor \& Francis Ltd, London.

Shukla, A., Tiwari, G.N., Sodha, M.S., 2009. Embodied energy analysis of adobe house. Renew. Energy 34, 755-761. https://doi.org/10.1016/j.renene.2008.04. 002 .

Venkatarama Reddy, B., Jagadish, K., 2003. Embodied energy of common and alternative building materials and technologies. Energy Build. 35, 129-137. https://doi.org/10.1016/S0378-7788(01)00141-4.

Venkatarama Reddy, B.V., 2009. Sustainable materials for low carbon buildings. Int. J. Low Carbon Technol. 4, 175-181. https://doi.org/10.1093/ijlct/ctp025.

Venkatarama Reddy, B.V., Prasanna Kumar, P., 2010. Embodied energy in cement stabilised rammed earth walls. Energy Build. 42, 380-385. https://doi.org/10. 1016/J.ENBUILD.2009.10.005.

Wadel, G., Avellaneda, J., Cuchí, A., 2010. La sostenibilidad en la arquitectura industrializada: cerrando el ciclo de los materiales. Inf. la Construcción 62, 37-51. https://doi.org/10.3989/ic.09.067.

Zabalza Bribián, I., Valero Capilla, A., Aranda Usón, A., 2011. Life cycle assessment of building materials: comparative analysis of energy and environmental impacts and evaluation of the eco-efficiency improvement potential. Build. Environ. 46, 1133-1140. https://doi.org/10.1016/j.buildenv.2010.12.002.

Zackrisson, M., Rocha, C., Christiansen, K., Jarnehammar, A., 2008. Stepwise environmental product declarations: ten SME case studies. J. Clean. Prod. 16, 1872-1886. https://doi.org/10.1016/J.JCLEPRO.2008.01.001. 